


MA35. EA36. 2: En 29

Massachusetts Department of Environmental Protection UMASSIAMHERST

Division of Wetlands and Waterways

\section{An Enforcement Manual for Wetlands Protection in Massachusetts}

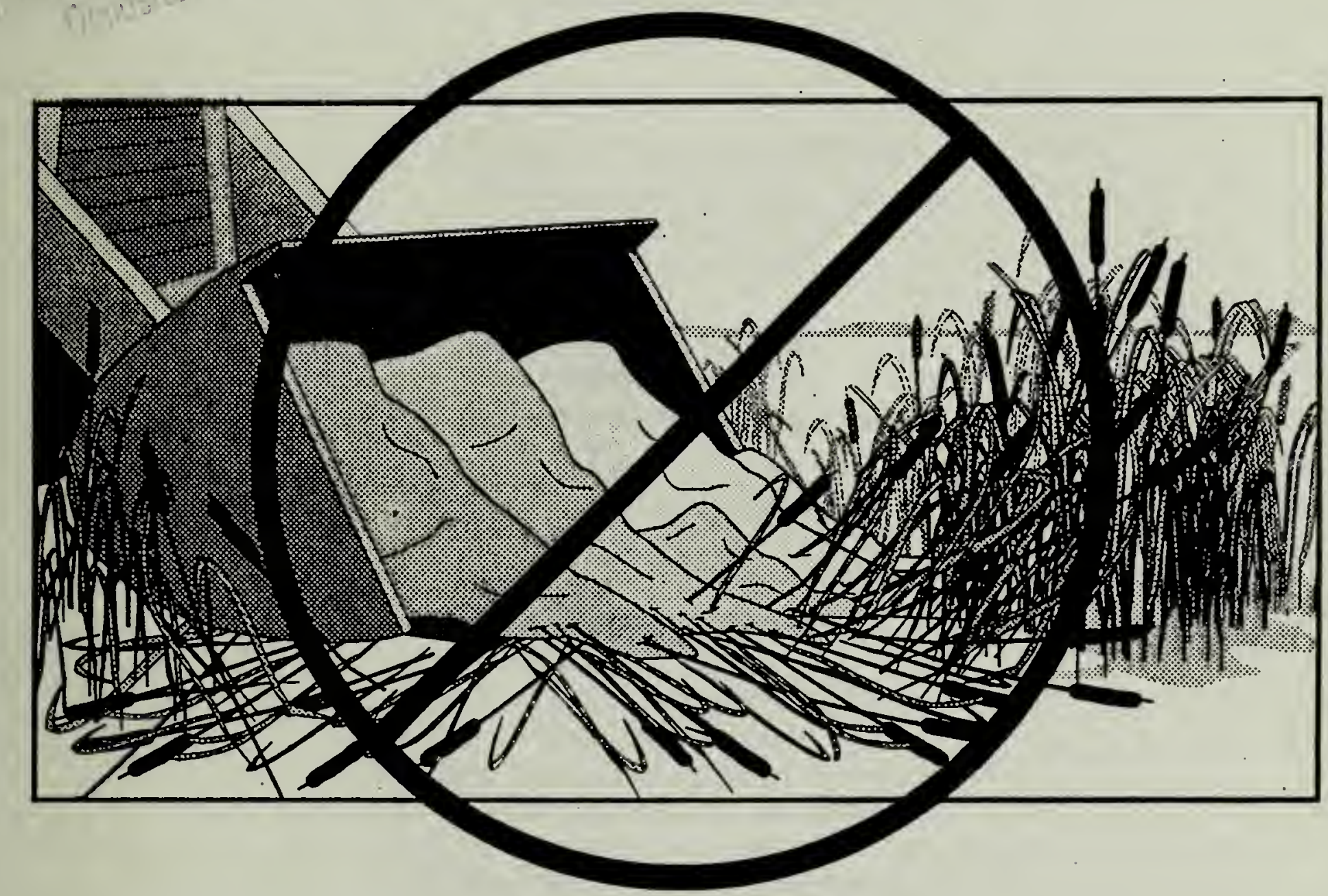

This publication has been prepared for use in DEP's ongoing technical assistance and training program for Conservation Commissions. 



\title{
An Enforcement Manual for Wetlands Protection in Massachusetts
}

This publication is the 1994 update of the Department of Environmental Protection, Division of Wetlands and Waterways' Enforcement Manual, originally published in 1990. The revisions that have been made to the document reflect recommended changes to enforcement techniques and procedures over the last several years. The manual may be used as a supplement to the Division's videotape, "Enforcement of the Wetlands Protection Act."

\author{
Revised in 1994 by: \\ MA Department of Environmental Protection \\ Bonney Cashin, Office of General Counsel \\ Elizabeth Kimball, Office of General Counsel \\ Carl Dierker, Acting Director, \\ Division of Wetlands \& Waterways \\ Environmental Strike Force \\ Anne Kelly, Director \\ Originally Prepared in 1990 by: \\ McGregor, Shea \& Dolinor. P.C. \\ 18 Tremont Street, Suite 900 \\ Boston, MA 02108 \\ Author: Lois Bruinooge \\ Research: Susan Brent \\ Reviewed by: Gregor McGregor \\ Commonwealth of Massachusetts \\ William F. Weld, Governor \\ Executive Office of Environmental Affairs \\ Trudy Coxe, Secretary \\ Department of Environmental Protection \\ Daniel S. Greenbaum, Commissioner \\ Bureau of Resource Protection \\ Arleen O'Donnell, Asst. Commissioner \\ Division of Wetlands and Waterways \\ Carl F. Dierker, Acting Director
}

MA Department of Environmental Protection

Division of Wetlands and Waterways, 

DEP ENFORCEMENT MANUAL FOR CONSERVATION COMMISSIONS

What To Do First; What to do Next

TABLE OF CONTENTS

Quick Reference Guide to the Enforcement Manual.......... A-B

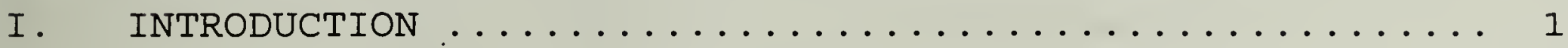

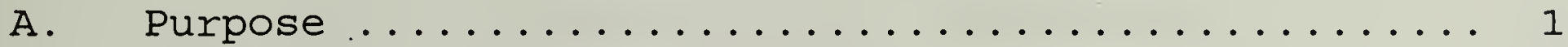

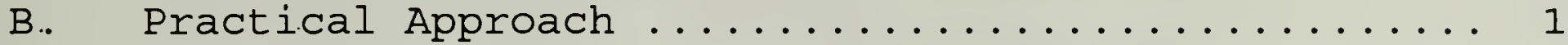

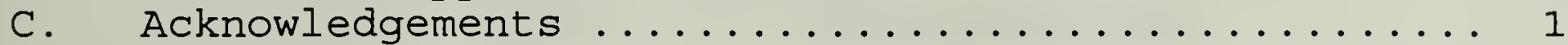

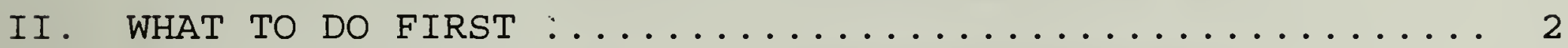

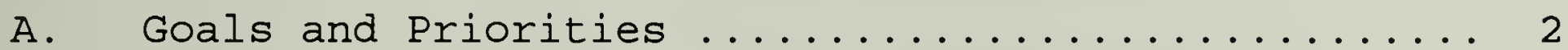

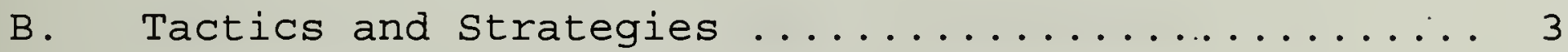

C. Set the Stage for Easy Enforcement ............. 3

1. Make sure your conservation commission is

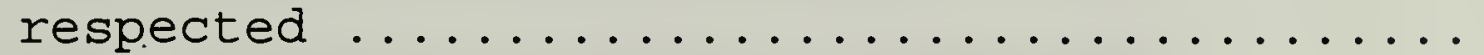

2. Forge communication links with other municipal boards and departments now, well before your next enforcement crisis .... 4

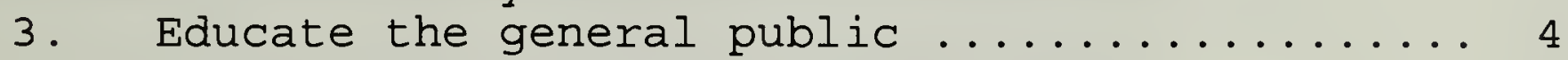

4. Use the media effectively ................ 5

5. Write Orders of Conditions that are virtually self-enforcing .............. 5

6. Respond swiftly and clearly to any violations that do occur ............... 5

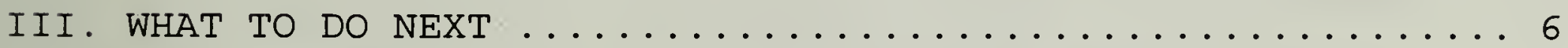

A. Jurisdiction $\ldots \ldots \ldots \ldots \ldots \ldots \ldots \ldots \ldots \ldots \ldots \ldots \ldots \ldots \ldots \ldots$

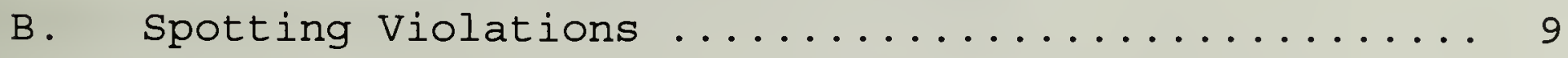

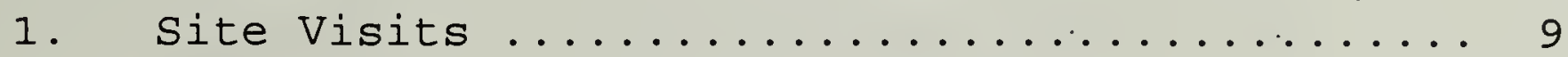

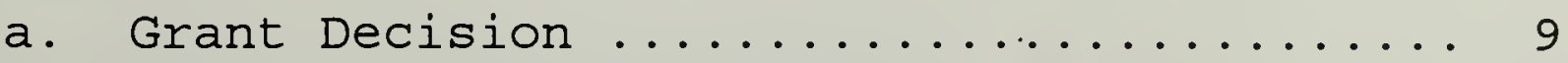

b. Landowner Consent/Civil vs. Criminal...... 11

c. "Public View" .................... 13

2. Obtaining Search Warrants .............. 14

a. Who Can Obtain a Search warrant .........14

b. Standards for Obtaining a Search Warrant. 14 
C. Documenting the Facts ................. 16

D. Taking Photos ......................... 16

E. Keeping a $\log \ldots \ldots \ldots \ldots \ldots \ldots \ldots \ldots \ldots \ldots \ldots$

F. Informal Enforcement ................ 18

1. Phone Calls ..................... 18

2. Meetings with Violators ............... 19

3. Correspondence ................... 20

G. Formal Enforcement ................... 21

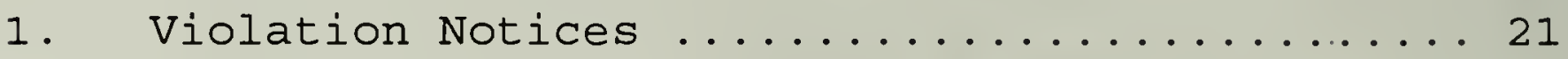

2. Enforcement Orders ................. 21

a. Drafting the Enforcement Order ....... 22

b. Issuing the Enforcement Order ........ 23

3. Revoking Orders of Conditions ........... 24

4. Non-Criminal Citations Using Local Bylaws .... 26

10/93 Update Note ............... 26

a. Implementing Section $21 \mathrm{D} \ldots \ldots \ldots \ldots \ldots \ldots 27$

b. Issuing the Citation ............ 28

c. Collecting the Fine ............. 28

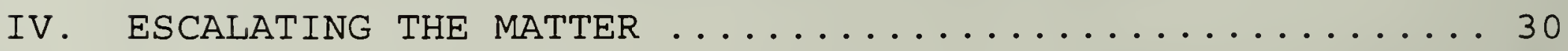

A. Suing the Violators ................... 30

1. Statute of Limitations ............ 30

2. Selecting Criminal vs. Civil Enforcement..31

B. Civil Court Action .................... 33

1. Filing the Complaint ............ 33

2. Temporary Restraining Order (TRO) ..... 33

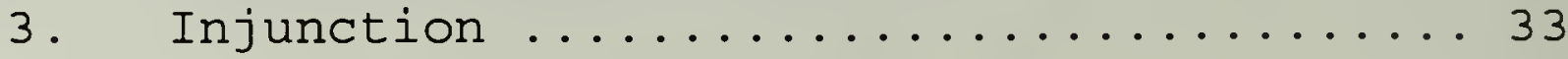

C. Criminal Prosecution ............... 35

1. Application for a Criminal Complaint ... 35

2. Prosecuting the Complaint .......... 35

3. Criminal Penalties .............. 36 
V: INVOLVING OTHER AGENCIES IN ENFORCEMENT ACTIVITIES $\ldots . .37$

A. Involving $\mathrm{DEP} \ldots \ldots \ldots \ldots \ldots \ldots \ldots \ldots \ldots \ldots \ldots \ldots \ldots$

B. Involving the Environmental Strike Force ....... 38

C. Involving Local Boards .............. 38

1. Board of Health ............... 38

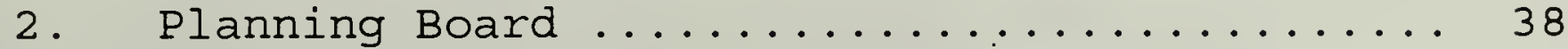

3. Building Inspector .................. 39

4. Zoning Board of Appeals ............... 39

VI. LIABILITY FOR ENFORCEMENT MISTAKES ............ 40

A. Personal Liability ................... 40

B. Mandamus ........................ 40

C. "Takings" ....................... 41

VII. OTHER PROGRAMS RELEVANT TO WETLANDS PROTECTION ...... 43

A. Chapter 91/Waterways Regulation Program ........ 43

B. Coastal and Inland Wetland Restrictions .......443

C. Massachusetts Environmental Policy Act (MEPA) . . . 44

D. Administrative Penalties ............... 45

E. Water Quality Certification .............. 45

F. Federal Clean water Act, Section $404 \ldots \ldots \ldots 6$

G. Public Nuisance Suits ............... 46

VIII. PRIVATE REMEDIES $\ldots \ldots \ldots \ldots \ldots \ldots \ldots \ldots \ldots \ldots \ldots \ldots \ldots \ldots$

A. Nuisance Suits ................... 48

B. Citizen Suits ................... 48 
IX. APPENDIX

A. Order of Conditions (Administrative and Monitoring Paragraphs)

B. What to Bring on Site Visits: A Suggested Checklist

C. Chapter 388, Acts of 1990 (amendment to MGL C.131, §40)

D. Civil Administrative Search Warrant Forms (application, affidavit, administrative warrant, and return)

E. Inspection/Violation Report

F. Violation Notice

G. Enforcement Order (with Restoration Clause)

H. 21D Bylaw for Non-Criminal Citation

I. Citation under 21D

J. 21D Procedures Guide

K. Application for Temporary Restraining Order, Preliminary Injunction and Permanent Injunction

L. Affidavit for Application for Temporary Restraining Order, Preliminary Injunction and Permanent Injunction

M. Application for a Criminal Complaint

N. Sample Site Inspection Letter

X. CONTACT/REFERENCE LIST 


\section{QUICK REFERENCE GUIDE TO THE ENFORCEMENT MANUAL}

If a violation is reported to your conservation commission:

Check files: Is site governed by an Order of Conditions?

yes

Does Order give conservation commission permission to enter property for site inspection? See pages 9-13 and Appendix A. $\underline{\text { no }}$

Can landowner permission be obtained to inspect site?

If yes, notify landowner of visit and inspect site. See pages 9-13, 16-17, and Appendix B, N.

If no, inspect site from public property or from neighboring properties or obtain a search warrant. See pages 9-17 and Appendices B-D.

Determine if a violation of the Wetlands Protection Act has occurred:

Is there a violation over which the Commission has jurisdiction? See pages 6-8.

yes

$\underline{\text { no }}$

Seek compliance through techniques that will get results.

No enforcement action necessary.

Start with informal, less confrontational methods such as phone calls, meetings, and written notices of the violation. See pages 18-20 and Appendices E-F.

Does violator respond to your enforcement efforts?

yes

Complete paperwork and monitor activity to ensure compliance. See page 17 . $\underline{\text { no }}$

Seek compliance through more formal options as listed on the next page of this Reference Guide. 


\section{QUICK REFERENCE GUIDE TO THE ENFORCEMENT MANUAL}

If more serious enforcement action is necessary:

Issue an Enforcement Order. See pages 21-23 and Appendix G. and/or

Consider Revoking the Order of Conditions. See pages 24-25. and/or

Issue a non-criminal citation using a local bylaw. See pages 26-29 and Appendices H-J.

If even more serious enforcement action is necessary:

Have you exhausted all town resources?

yes

Notify DEP and. request enforcement assistance. See page 37 .

and

Notify other agencies that may be able to offer enforcement assistance. See pages 43-4.6.

and

Request assistance from concerned citizens. See pages 46-48. $\underline{\text { nO }}$

Initiate legal

proceedings. Ask town

counsel to file a

civil complaint seeking a TRO and an injunction that will bring about compliance.

See pages $30-34$ and

Appendices $\mathrm{K}-\mathrm{M}$.

and/or

File a criminal complaint. Seek assistance from your police and the county DA. See pages 35-36 and Appendix M.

and

Notify other town agencies that may be able to offer enforcement assistance. See pages 38-39. 
What to Do First; What to do Next

I. INTRODUCTION

A. Purpose

The purpose of this manual is to assist conservation commissions and other municipal officials in protecting wetland resources. Enforcement is the key to an effective local wetlands protection program. Consistent, strong enforcement policies will reduce commission headaches in the long run and ultimately prevent deterioration of Massachusetts' wetland and water resources.

B. Practical Approach

This step-by-step manual will guide you through the maze of enforcement options, from the simplest, least threatening, and least expensive methods to more complicated and time consuming court actions. An orderly progression of enforcemerit techniques, designed to ensure compliance with as little hassle as possible, is presented along with the advantages and disadvantages of each method. The manual also contains practical tips drawn from experienced conservation commissioners, DEP staff, and attorneys who have successfully prosecuted wetland violations in court.

C. Acknowledgments

We would like to thank the following agencies and organizations for their assistance in producing this manual: the Massachusetts Association of Conservation Commissions; Middlesex County District Attorney's Office, for use of material from the Handbook on Criminal Enforcement of the Wetlands Protection Act; North Andover Conservation Commission; Attorney General's Office; Executive Office of Communities and Development, for use of material from $\underline{A}$ Guide to the Procedures for Implementation of the Noncriminal Method of Disposition of Violations of Municipal ordinances, Bylaws, Rules and Regulations; and Massachusetts Society of Municipal Conservation Professionals. 
A. Goals and Priorities

The goal of wetlands enforcement is to secure prompt and continued compliance under the Massachusetts Wetlands Protection Act and if applicable, your community's local bylaw. Sounds easy, right? It can be - if your conservation commission knows the law, sets enforcement priorities, develops an enforcement plan, and sticks to it. Enforcement does not have to be an overwhelming, frustrating task if your commission uses proven strategies that work.

Commissions can and should. act before a crisis to make enforcement easier in the future. Your commission will find itself in an endless tangle of paper, with less than adequate results, if the only response to a wetland violation is to issue an Enforcement order and hope for compliance.

The first step is to spend part of your next commission meeting listing your most pressing enforcement problems. Do you spend months debating what enforcement steps, if any, to take? Do you spend week after week listening to homeowners tell you they didn't know their backyards were wetlands? Did your last Enforcement Order fail to elicit a response from the violator? Did the selectmen turn down your request for town counsel's assistance because they didn't understand what you were talking about?

Try to make sense of these problems by analyzing their cause. Are you having trouble preventing violations because people simply do not know the law?. Or are violations flagrant because the local development community isn't afraid of getting caught? Do you spend more time than necessary on wetlands enforcement because no one on the commission knows what options are available, and legal? Is your commission so overwhelmed that small violations can't be corrected before they become serious problems.?

Take these insights and turn them into priorities for action. Write them down - it's the start of your Enforcement Plan.

* Top priority is to prevent violations from occurring in the first place.

* Second priority is to remedy serious violations quickly if they endanger the health, safety, and welfare of the community, or cause irreparable harm to the environment. 
Third priority is to catch minor violations early, so they don't become serious.

B. Tactics and strategies

All tactics and strategies flow from the ultimate enforcement goal - prompt and continued compliance - and from the priorities your commission has identified.

Assuming your commission's top priority is to prevent wetland violations from occurring in the first place, the following tips and methods can and should be implemented now. Time spent today implementing these suggestions will be more than repaid in the future as your commission reaps the benefits of good planning and efficient techniques. Most of the suggestions in this section can be incorporated into the commission's routine with little or not additional cost.

Make sure that whatever strategies seem best for your community get written into an Enforcement Plan. This "Plan" doesn't need to be very long or formal - a one-page outline is fine - but by setting your goals, priorities, and strategies down on paper, you already will have made enforcement easier by letting the community know you are serious.

C. Set the Stage for Easy Enforcement

1. Make sure your conservation commission is respected.

Start by conducting commission affairs in a professional, business-like manner. This will let the community know that you are serious about wetlands protection and about enforcement of wetland laws. Keep detailed minutes of commission meetings and site visits. Tape record each meeting. Have agendas available for members of the audience. Invite audience participation when appropriate, but don't lose control of the meeting.

Be consistent if and when you do take enforcement actions. Each commission member should be well-educated as to his/her responsibilities and limitations under the law. Don't shoot from the hip - cite from the applicable law, regulation, or policy to justify your decisions. Never try to extend the authority given commissions by law.

Don't make idle threats, but be willing to escalate when necessary to prevent serious harm to the environment and to send a strong message to flagrant violators that their actions will not be tolerated. 
Appoint one commission member as the "Enforcement Coordinator" for your community. This person should be familiar with the options presented in this manual and feel comfortable enough to take charge when enforcement is needed. The Enforcement Coordinator should be the main contact person for commission enforcement actions.

2. Forge communication links with other municipal boards and departments now, well before your next enforcement crisis.

Explain to your selectmen and, especially, town counsel, the nature of wetlands protection, the type of violations encountered, and the typical need for fast action. Apologize in advance for short notice in emergencies, and give them copies of the Wetlands Protection Act and Regulations, your local wetland bylaw, and a copy of this Enforcement Manual. Also, be sure to show them a copy of your Enforcement Plan, and let them know you take your responsibilities very seriously.

Ask the planning board, board of appeals, and board of health for fifteen minutes of time at their next meetings so that you can make a short presentation about wetlands protection. Provide board members with handouts describing wetland resources so that they can alert you to possible violations. Brochures summarizing the wetlands Protection Act are available from the Massachusetts Association of Conservation Commissions (MACC) and the Massachusetts Audubon Society. (See Contact/Reference List). Meet with municipal staff, such as the building inspector, engineers, and road department to familiarize them with wetland issues. Explain to the police chief when police services might be needed to assist the commission in enforcing wetland laws. The alternative is to cram this preparation into a few short minutes or hours when enforcement is imminent.

3. Educate the general public.

Start building a foundation today of community-wide awareness. Townspeople will be more likely to support your efforts if they know that you exist and understand what you are trying to accomplish. Well-informed neighbors can.alert you to potential violations, and will support your request for the resources necessary to do the job right. General awareness within the community will prevent many of those "I didn't know I couldn't put my swimming pool in a wetland" violations. 
Publicize your activities, meetings, and site visits. Visit neighborhood groups, garden clubs, and civic organizations for short presentations to explain the work of the conservation commission. Get involved in the school system with river cleanups, nature walks, and other activities geared toward school children and their parents.

4. Use the media effectively.

One of the best ways to educate the public is to get favorable press coverage. Invite members of the local press to cover your meetings. Designate a commission member to be responsible for sending meeting agendas to local reporters, highlighting those items that might be of interest. Compiling addresses on reproducible, peel-off label sheets makes this job easier. It is also a good idea to submit feature articles on wetland issues and the activities of the conservation commission. Write letters to the editor, and suggest topics for formal editorials. Be patient with inexperienced reporters and explain your duties under state and local law again and again.

5. Write Orders of Conditions that are virtually selfenforcing.

Many violations can be prevented if the developer-contractor has a clear understanding of what is required before any work begins on site. Sample conditions that make this job easier are found in Appendix A. Make sure the Order of Conditions is recorded in the Registry of Deeds before work begins, so that subsequent owners of the property know what their obligations are. Each order must be recorded prior to any work commencing on site (but after all appeal periods have lapsed) in the Registry of the county where the land is located. The applicant must notify your commission when the Order has been recorded by returning the bottom portion of the Order of Conditions form. If the applicant does not record the order before commencing work, your commission may record the order.

6. Respond swiftly and clearly to any violations that do occur.

The most logical sequence of enforcement action is set out in the following sections. Start simply and informally, but don't be afraid to take more aggressive action if your original request has not been complied with. 


\section{WHAT TO DO NEXT}

A. Jurisdiction

The first step in determining whether a violation of the Wetlands Protection Act, G.L. C.131, s.40, has occurred is to decide whether the activity you have observed is 1) regulated under the Act and 2) falls within an area subject to the commission's jurisdiction. Remember that work alone does not establish jurisdiction, and jurisdiction itself does not establish that the work will be prohibited.

The first paragraph of the Wetlands Protection Act states: "No person shall remove, fill, dredge or alter any bank, fresh water wetland, coastal wetland, beach, dune, flat, marsh, meadow or swamp bordering on the ocean or on any estuary, creek, river, stream, pond, or lake, or any land under said waters or any land subject to tidal action, coastal storm flowage, or flooding... without filing written notice of this intention... (with) the conservation commission ..." G.L. C.131, s.40.

The Department of Environmental Protection (DEP) has promulgated Regulations, 310 CMR 10.00, which clarify and further define the activities and resource areas which are subject to protection under the statute.

The work covered by the statute is defined in the Regulations to include virtually any development activity. "Alter," the key word, is defined broadly enough by DEP to reach most development impacts including changes in drainage, salinity, sedimentation, water flow, flood retention, water levels, water temperature, or other physical, biological or chemical characteristics of the receiving water.

The Resource Areas which are protectable under the Act are those listed in the statute and classified in the Regulations as bordering vegetated wetlands, land subject to flooding (both isolated and bordering), land under water, banks, beaches, and dunes. To be protectable under the Act most of these Resource Areas must border any one of a list of water bodies - lakes, creeks, streams, rivers, ponds, estuaries, or the ocean.

For work in a Resource Area, a Notice of Intent must be filed with the conservation commission before work can proceed. Jurisdiction here can be thought of as "automatic." The commission can and should use its authority to stop unpermitted work in a Resource Area until a Notice of Intent has been filed and an Order of Conditions has been. issued and recorded. 
In contrast, work in a 100-foot Buffer Zone around bordering vegetated wetlands, banks, beaches, and dunes may be governed by the Act, and the developer has the option of filing a Notice of Intent or a Request for Determination. Jurisdiction in this Buffer Zone might be thought of as "advisory." Unauthorized work in the Buffer Zone also should be stopped until either a Request for Determination or a Notice of Intent has been acted upon by the commission or DEP upon appeal.

Finally, work outside any Resource Area or Buffer Zone is regulated only when and if an alteration of a Resource Area occurs. In other words, work altering wetlands and floodplains from a distance (as through changes in drainage, discharges of pollution, and siltation from erosion) requires a permit from the conservation commission only after the alteration actually takes place. This could be called "after-the-fact" jurisdiction. If work outside a Resource Area or the Buffer Zone has altered a Resource Area, the commission can and should stop all work until a Notice of Intent has been filed and an Order of Conditions has been issued and recorded.

The commission retains jurisdiction over a project once an Order of Conditions or a Determination of Applicability has been issued. Failure to comply with a Determination or an Order of Conditions constitutes a violation of the Act. Violations can include, among others, failure to observe a particular condition or time period specified in a Determination or Order, failure to record an Order in the Registry of Deeds, or continuation of work after failing to obtain an Extension Permit.

The conservation commission and DEP equally are authorized and responsible for enforcing the Act. This means that a conservation commission, at its discretion, can enforce a DEP Superseding Order. DEP, at its discretion, can enforce a conservation commission Order issued under the Act. Both DEP and the conservation commission can pursue a violation where work is being done in an area subject to the Act without a valid Order of Conditions.

If your community has a wetland bylaw, commission jurisdiction may be defined more broadly than under the Act. Additional resource areas may be protected, and additional activities may be regulated. Sample wetland bylaws are available from MACC. (See Contact/Reference List.) Commissions with wetland bylaws have independent authority to assert jurisdiction over work in or near resource areas. Determinations of Applicability, Orders of Conditions, Enforcement Orders, and other documents issued under local bylaws should clearly state that they are being issued 
pursuant to local authority. In appropriate cases, jurisdiction under a bylaw can be asserted concurrently with jurisdiction under the Act. If only one document (i.e. an Order of Conditions) is issued pursuant to both the Act and a local law, each law should be cited on the document's face. Remember that wetland bylaws are local responsibilities; DEP cannot assist conservation commissions in implementing or enforcing them. 
Wetland violations are bound to occur despite commission precautions, so you may as well do everything possible to spot them early in order to prevent disasters. It is vital for the community and the media to know of your work, because only then can they bring potential violations to your attention.

1. Site Visits

In order to establish whether an activity is in violation of the Wetlands Protection Act or local bylaw, your commission usually will need to conduct a site visit. A site inspection is not subject to the Open Meeting Law and may be conducted. by one or any number of commission members. In important cases the entire commission may visit the site together; for smaller projects or emergencies the job may be delegated to one member. In any case, a routine procedure should be established. A checklist of items your commission should bring on site visits is included in Appendix $B$.

The Wetlands Protection Act contains language giving conservation commissions authority to enter private land in order to carry out their duties under the Act, but it is not the last word on the subject. Both the United States and Massachusetts Constitutions contain important safeguards that protect people from unreasonable searches and seizures. When there is a conflict between. statutory and Constitutional provisions, the Constitutional protections will prevail.

a. Grant Decision.

In Commonwealth V. John G. Grant and Sons, Inc., 403 Mass. 151 (1988), the Massachusetts Supreme Judicial Court concluded that commissions do not have legal authority to conduct inspections on private property for violations of the Wetlands Protection Act. The Court based its decision on a narrow reading of the language of the Act, concluding that commissions have authority to enter private property to carry out administrative functions in the processing of notices of intent but not to carry out.enforcement functions.

Chapter 388, Acts of 1990 (see Appendix C), amended M.G.L. ch. 131, s.40 to explicitly include enforcement as one of a conservation commission's functions. Conservation commissions now clearly have authority to enforce the Act, and may undertake any enforcement actions authorized by law. This statutory amendment this corrects the major flaw in wetlands enforcement identified in the Grant decision. 
Because conservation commissions now explicitly have enforcement authority, the language of M.G.L. ch.131, s. 40, paragraph 12 is applicable to them: "[t] he conservation commission and.its agents ... and the Commissioner of [DEP] and his agents ... may enter upon privately owned land for the purpose of performing their duties under this section."

However, this language must still be viewed in conjunction with federal and state constitutional protections against unreasonable searches. It is clear that the justices were concerned with an interpretation of the Wetlands Protection Act that would grant conservation commissioners inspection authority that was overly broad. The decision states that: "[a] general grant to roam at will through all areas in a municipality that are subject to s.40 in search of unlawful conduct would present substantial constitutional questions." The court also noted that unlike the U.S. Supreme Court, the Massachusetts courts have not yet addressed the "open

fields" exception to the constitution that allows warrantless searches of open fields, woods and other outdoor areas that are not in proximity to a home, business or other location where a landowner would have an expectation of privacy.

In view of the unsettled nature of the caselaw in this area, a conservation commissioner attempting to make a site inspection to determine whether a wetlands violation has occurred should carefully study the following analysis. 
Your enforcement actions will fall into one of two categories: civil administrative enforcement (seeking compliance prospectively with the statute and/or monetary fines) or criminal enforcement (seeking punishment for past violations of the statute, including monetary fines and/or imprisonment). [See text at page 31 for further discussion of the differences between civil and criminal actions.] In cases where criminal actions are contemplated, site inspections should be conducted under the auspices of the police department or district attorney, generally with a warrant. For various reasons, the vast majority of your enforcement activities will involve civil administrative enforcement actions. In civil cases where the area to be inspected is not in the proximity of a home or business, the following procedure should be sufficient:

1. First, go to the home or business during normal business hours (i.e., 8:30am -. 5pm, Monday through Friday) and announce your presence. If there is no structure on the property, approach anyone working on the site and ask to be directed to the landowner or any other person in charge. Introduce yourself as a member or agent of the conservation commission and show some identification, such as a badge or photo. ID that contains some reference to your official capacity, if possible. Explain that you are investigating complaints that there is work at the site that is being carried out in violation of the Wetlands Protection Act and that you would like to conduct a site inspection to determine whether such violation has in fact occurred. If there is no objection, proceed with your inspection in a professional manner.

2. If the landowner or other person with whom you are speaking objects at any time to your investigation, either verbally or by his/her actions, DO NOT proceed further with your site inspection: For your own safety, as well as constitutional considerations, you should get off the property immediately. You may proceed with your investigation only by observing any violations that are in public view (as described in "c", below) or by obtaining a search warrant (as described in "2", below).

Sometimes there may not be anyone at the site at the time of your inspection and you will have to determine who the property owner is. 
3. If your repeated attempts to contact the landowner

(either in person or by telephone) have been

unsuccessful, another option is to write a letter to the landowner, telling him or her that you will be on the site on a certain date to conduct an inspection. Be sure to include in the letter information about how the. landowner can contact you if they object to your inspection. (See sample letter, Appendix N.) Send the letter certified mail return receipt requested. If you know that the individual received the letter (i.e., you have received back the green return receipt requested card, signed by the landowner), you can assume you have his or her consent to enter. However, you must have allowed a reasonable response time and have heard no objections in that time. If you think someone other than the landowner has authority to permit you on the site, contact your town counsel.

4. If you are unable to contact the landowner, either in person, by telephone, or by letter (N.B., be sure to keep a log of your attempts to contact the landowner) because there is no one at the site or because you are unable to reasonably determine who the owner is, and the area of violation is not in public view, you should contact your town counsel to discuss your strategy on gaining access. While obtaining a warrant is always an option, s/he may have an alternative recommendation, depending on the particular circumstances of the situation.

Any landowner who files a Request for Determination or Notice of Intent with the conservation commission cannot reasonably be expected to deny commission access to the property.. By filing an application.with your commission, the landowner in effect has consented to a site visit. ${ }^{1}$ If permission to conduct a site visit for acting upon a Request for Determination is withheld, your commission can issue a Positive Determination and require a full Notice of Intent before any work proceeds on site. If permission to conduct a site investigation for acting upon a Notice of Intent is withheld, your commission can deny the landowner's application for lack of information.

'The Department's position on this issue has recently been challenged in court. DEP's acting wetlands director and a member of the MACC board of directors have filed affidavits in support of a coniservation commission's right to conduct a site inspection under these circumstances. Further guidance will be provided when a final decision has been issued. 
Similarly, once the appeal period for an order of Conditions has elapsed and work has begun, the landowner in effect has consented to its conditions. When issuing an Order of Conditions under the Act or your local bylaw, include a paragraph stating that the commission, its employees, and agents shall have a right of entry to inspect for compliance with the terms of the Order. Sample language is included in Appendix A.

c. "Public View"

Where possible, observe violations from public property or from private property where you have permission to be, such as on abutting land. Ask a neighbor if you may enter his/her property to observe the adjoining lot. You also may view violations from any vantage point where the public is not excluded, such as streets, parking lots, sidewalks, public parks, and so forth. Keep notes of your observations and photographs made from such locations. For serious violations, consider renting an airplane. If several ongoing violations occur or are suspected, it would be worth the additional expense to contract for aerial photographs at regular intervals (perhaps every 2-3 years). Historical aerial phctos can also be obtained from a variety of sources, including the Mass. Dept. of Public Works or DEP's Wetlands Conservancy Program (see Contact/Reference List). 
If the landowner objects to your entry, and you still need to enter the property to inspect for potential violations, you will need a search warrant.

a. Who Can Obtain a Search Warrant

A member or an agent of your commission may apply for a search warrant and conduct the search. Be prepared to document the reasons why you suspect a violation is occurring or has occurred on the site, the measures you have taken to gain compliance, and the seriousness of the alleged violation. If you are concerned about your personal safety during a site inspection, you may wish to contact your local police department so that they can accompany you during your inspection and prevent any breach of peace.

b. Standards for Obtaining a Search Warrant

For most enforcement actions, you will be seeking a civil administrative search warrant. The standard for obtaining an administrative warrant is a more relaxed standard than the standard for obtaining a criminal search warrant. To obtain an administrative search warrant, the conservation commission must demonstrate that the search is part of a neutral inspection scheme (for example, the commission decides to inspect every site for which it issues an Order of Conditions) or the commission has specific evidence of an existing violation.

In order to obtain a criminal search warrant, you must meet the "probable cause" standard. This means that you must demonstrate to a magistrate or judge that you have reliable information leading you to believe that evidence of a violation of law will be found on the property to be searched. If you wish to pursue criminal prosecution of a violation, you will need to obtain a criminal search warrant through the District Attorney's office.

To obtain a civil administrative search warrant, go to the civil, not the criminal, clerk's office of the local District or Superior Court. Make sure the clerk understands that you are seeking a civil - not a criminal - search warrant. It is recommended that you bring a copy of the Act, as amended in 1990, with you when you apply for the warrant. Be prepared to submit the following information in support of your application for a civil administrative search warrant (See Appendix D for Civil Administrative Search Warrant forms): 
1. Describe the property in detail, including ownership, existence of any dwelling, a description of that portion of the premises subject to C. 131, $\$ 40$, and what the commission expects to observe on the site;

2. Describe the source of reliability and contents of information giving the commission reason to believe that evidence of a violation will be observed;

3. Describe any attempts to obtain consent and view the property from another lawfully attainable position off site; and

4. Describe the commission's authority to enforce the law, citing appropriate sections of the Wetlands Protection Act and Regulations, as well as your local wetland bylaw.

A search warrant will be issued by a judge or clerk magistrate to you, if they find you have demonstrated "administrative probable cause." You then conduct the search and return the warrant and the return form to the issuing court. 
Assuming that you are now lawfully on the site, whether by consent or with a search warrant, the next step is the site inspection. First of all, search only the areas where you have permission to be. Do not. "roam at will." Your purpose is to gather facts about a possible violation. Appendix $B$ reviews what to bring with you.

All facts collected during site inspections should be recorded. It is important to build a complete, accurate record of each violation while the incident is still fresh in your mind, in order to take effective enforcement action later. The Middlesex County District Attorney's Office has developed a Violation Report Form that can be tailored to your community, photocopied, and distributed to each member of the commission. (Keep them in your auto glove compartment!) The form should be filled out immediately, whether or not court action is anticipated, as it provides a good foundation for all subsequent enforcement action.

If viewing the violation from a public place or private property where you have permission to be, record as many facts as you can observe.

A sample. Violation Report Form is included in Appendix E. It provides space to record the property location, owner, responsible parties, vehicle registrations, activities, type of wetland, witnesses, and action taken by the police or conservation commission. Remember to collect information for each separate date on which illegal filling, dredging, removing, or altering takes place.

Try to document the nature and condition of the property as it existed before the wetland violation. Utilize U.S. Geological Survey topographic maps, Federal Emergency Management Agency floodplain maps, U.S. Soil Conservation Service soil maps, DEP wetland restriction maps, and municipal wetland maps as general aids to determine the wetland boundary prior to an illegal alteration.

Photographs from neighbors, or from aerial surveys, may be helpful.

D. Taking Photos

Photographs documenting a violation are essential. Thèse should be prints, preferably in color and ideally 5" $x$ " or 8" $x$ 10". (An instant camera will not produce such large shots, but is convenient in the. field). On the reverse side of each print should be noted, in waterproof ink, the exact date and time of the photograph, the subject of the photo, the name, title, and address of the photographer, a brief 
description of the location from which the photo was taken and in what direction, and the name and address of any individual present when the photo was taken. Try to include a reference point for scale, such as a ruler or standing person, and include landmarks whenever possible.

E. Keeping a Log

Once a violation has been observed, start a file on the property or resurrect an existing file. Begin each file with a log sheet which records all enforcement activities, from site visits, phone calls, and correspondence to formal enforcement measures. A log can be an invaluable tool in making sure that information on a violation is thorough and orderly for court purposes. Every violation should be treated as if it could end up in court; by starting a log sheet now, you will avoid many headaches later. 


\section{Phone calls}

A simple phone call to the property owner may be all that is needed to secure compliance with the Wetlands Protection Act and local bylaw. In many cases the violation stems from ignorance of wetland protection laws, and education is the key to prompt and continued compliance. This doesn't mean you should always begin your enforcement efforts over the phone; for repeated or flagrant violations you may want to issue an immediate Enforcement order.

However, a phone call can be particularly effective when the activity is a small, home-improvement type of project. Inform the person of the violation and give simple corrective steps that should be taken immediately to prevent further damage. These might include the installation of hay bales, stabilization of the area with mulch, and voluntary suspension of all other work in the affected area. Make sure you give the violator explicit directions for carrying out these requests, and offer to visit the site with the violator to clear up any confusion.

Set a timeline for compliance, and include instructions for completing commission paperwork. Typically, work should be stopped upon receipt of the phone call; erosion controls should be put in place immediately ( $1-3$ days); and the violator should be instructed to appear at the next commission meeting with at least a sketch of the area and a description of the proposed project, as a prerequisite to a formal Request for Determination (RFD) or Notice of Intent (NOI). If damage to a Resource Area is extensive, or the project appears complicated, the commission may dispense with an informal meeting and request an RFD or NOI be filed as soon as possible (within 2-3 weeks is reasonable).

If you meet with resistance over the phone, explain the serious consequence of wetland violations and explain what steps the commission may take to ensure compliance. Do not ruin your credibility with idle threats, but outline the facts of enforcement - the next step may include an Enforcement Order, which will officially stop all work within areas under the commission's jurisdiction. Let the violator know that continued noncompliance may lead to substantial fines or a jail sentence or both. 
Detailed notes from this telephone conversation should be included in the file, and the date and time should be recorded on the log sheet. It is important to send a confirmatory letter summarizing the important corrective measures, procedures, and deadlines established over the telephone.

\section{Meetings with Violators}

Meetings with violators should be educational, not confrontational. This is your chance to educate the violator about the need for and the requirements of the Act, Regulations, local bylaw, and commission procedures. The violator should view this meeting as a chance to explain his/her project.

If the project is simple, in the Buffer zone, or no damage to a Resource Area has occurred, the commission may review the landowner's proposal and require only a Request for Determination be filed. If the project is close to a Resource Area, complicated, or if damage to a Resource Area has already occurred, the commission may request a Notice of Intent. However, if it is obvious that the project cannot meet regulatory performance standards (i.e. more than 5,000 sq. ft. of bordering vegetated wetland has been altered) your commission should not request a Notice of Intent be filed. Instead, your commission should issue an Enforcement Order and require the filing of mitigation-restoration plans. It may be appropriate to accept a Notice of Intent for one portion of a site and to issue an Enforcement Order requiring mitigation-restoration for another portion.

In any case, do not neglect the paperwork and public hearing requirements of the Act and local bylaw. Even if you feel this violation can be resolved with installation of a few haybales, make sure the paperwork gets completed and a public hearing is held. Time spent now, to create the proper record, will save your commission headaches in the future. Abutters need an opportunity to raise their concerns, and the landowner. will be protected from uncertainty if the procedural requirements are followed.

If the commission has not already set a deadline for receipt of the RFD or NOI, do so at the meeting. Decide whether the initial remedial measures and timeline are adequate for compliance. If necessary set a new schedule for work to be done, and reiterate the work which cannot be done, pending issuance of a final Determination or Order of Conditions. Be specific. Schedule another site visit if necessary. 
Follow up with correspondence to confirm all requests and deadlines. Once the appropriate meeting minutes have been approved, place a copy in the project file.

3. Correspondence

Follow up all conversations and meetings with the violator in writing. Confirm in writing all deadlines, procedures, and corrective measures agreed upon verbally. Make sure a copy of each document sent and received finds its way to the appropriate file. Remember to enter all enforcement activities, including the date and content of every piece of correspondence, onto the log sheet prefacing each file.

Enforcement correspondence can be hand delivered or sent by regular mail, registered mail, or certified mail return receipt requested. Use whatever method or methods will ensure prompt and continued compliance. Hand delivery, with a confirmatory copy by certified mail return receipt requested, will prevent the violator from claiming that he/she did not receive the document in a timely fashion. When necessary, an enforcement document can be delivered effectively by a local police officer. 
G. Formal Enforcement

1. Violation Notices

A written Violation Notice, on the commission's letterhead, is a more formal enforcement step than a phone call.

Violation. Notices can be effective to bring about compliance when phone calls are ignored. They also look "official" when delivered on site by the conservation agent or a commission member.

A sample Violation Notice is included in Appendix F. At a minimum, the Notice should contain space to record the property location and parties it is issued to, the extent and type of activity that is observed in violation of the Act or local bylaw, corrective measures, and deadlines for compliance. The Notice should contain a brief summary of the commission's authority to enforce the Act and bylaw, and should note the consequences of not responding. It should be signed by the agent or commission member who issues it.

Don't issue the Violation Notice without making a copy for the file, and remember to enter its issuance on the log sheet.

2. Enforcement Orders

No response to your phone call or Violation Notice?

Typically, the next step is to issue an Enforcement order under authority of the state Wetlands Protection Act and your local bylaw. This is not to say that an Enforcement Order is the only step which should be taken; repeated or flagrant violations may cause the commission to initiate legal action simultaneously. But generally, since an Enforcement order includes a strong incentive for compliance - a stop-work provision - try to obtain compliance with an Enforcement order before escalating the matter into a lawsuit.

The commission can pre-authorize its agent, or each individual member, to issue Enforcement Orders in the field. Simply vote at your next regular commission meeting to authorize individual commission members or staff to issue Enforcement Orders in the field when speed is of the essence to protect wetland interests. Any Order issued by one person should be ratified by the full commission at its next meeting. 
Enforcement Orders (formerly Cease and Desist Orders) should be issued using Form 9, 310 CMR 10.99, provided by DEP in the Wetland Regulations. This form is a good start, but an effective Enforcement Order is tailored to the situation and should include more information than called for on the standard form. If your community has a wetland bylaw, note on the form itself that the Enforcement order also is being issued under authority of the bylaw. The Enforcement Order should be a self-contained educational document, as it provides the basis for other more serious enforcement efforts. Attach as many pages to the form as necessary to convey your message. A sample Enforcement Order is included in Appendix G.

The Order should be addressed to all potentially responsible parties - owner, developer, contractor, and subcontractors, and describe the property where the illegal work has occurred. Draft the order to contain a short "Introduction" describing the commission and its authority to issue the Order; a section entitled "Facts" containing all information pertinent to the violation - who saw what, when and where; a section on the "Law," citing provisions of the Act, Regulations, and bylaw that have been violated; and a section entitled "Findings" tying these facts to the law.

The next and most important section is the "Order" which describes exactly what steps the commission wants the violator to take and sets deadlines for their completion. Draft these measures carefully to ensure understanding and compliance. The commission can halt all unauthorized work within its jurisdiction from the moment the Enforcement Order is received by the violator until the recording of an Order of Conditions. A map or sketch would be helpful here to identify exactly which areas are under the commission's jurisdiction and which activities are subject to the stopwork provisions of the Order.

An exception to the stop-work order should be made for emergency site stabilization and erosion control measures that must be installed immediately. Again, describe these measures clearly, set a specific deadline for completion, and offer to visit the site if necessary to clarify the commission's position. Further steps toward compliance with the Act and local bylaw should be staged; that is, do not merely request that the violator file a Notice of Intent "as soon as possible." Instead, require the violator to document in writing, by a set date, his/her intent to comply. Set deadlines for retaining an engineer (or other appropriate consultant), and for submitting a Notice of Intent. Additional on-site remedial steps should be stated 
in the same manner. Don't wait for a month only to find out that the violator has no intention of complying!

The Enforcement Order should contain a final paragraph noting the serious consequence of wetland violations. Don't threaten any particular action, but describe the penalties which may be imposed under the Act, local bylaw, and by DEP, under the state Administrative Penalties Program.

b. Issuing the Enforcement Order

The Enforcement Order should be signed by the commission. agent or as many commission members as possible. Remember to note on the Order that a copy has been sent to DEP, town counsel, the selectmen, town manager, planning board, board of appeals, board. of health, building inspector, and equally important, the local newspaper.

It is not a good idea to send a copy to the local bank holding a mortgage on the property, or to the real estate brokers who are showing the property for sale. To do so could put your commission in the position of interfering with a contractual relationship, and force you to defend an unwanted law suit.

The Enforcement Order should not be recorded in the Registry of Deeds, even though it may seem like a good way to attract the 'violator's attention. Based upon Massachusetts court decisions and statutes, only certain documents are entitled to be recorded, and an Enforcement order does not meet those requirements. The Wetlands Protection Act requires that Orders of Conditions be recorded, but it does not authorize the recording of enforcement documents. 
Where the requirements of an Order of Conditions have been seriously violated, you may want to consider revoking the Order. This is appropriate only in the most extreme and the most egregious cases, as this is a serious step. Your commission should attempt to gain compliance through other techniques prior to considering revocation. In almost all cases, an Enforcement Order should be issued first; this will put the violator on notice and will build a record if more serious enforcement efforts are necessary.

A revoked Order cannot be reinstated. If the order is revoked, the permit holder will have no permit to go forward on and will have to file a new Notice of Intent to continue work on the project. You are taking away a substantial right previously granted to the applicant; expect substantial opposition. You may want to speak with Town Counsel before taking this step, as the violator's only remedy is to seek review of your action in court.

In cases where a wetland resource area has been or will be damaged, your commission should revoke the Order and issue an Enforcement Order specifying the work necessary to stabilize. the site. Without such an Enforcement Order, the violator cannot do any work on site once the order of conditions is revoked. If a refiling is made, considerable delay may occur if the new Order of Conditions is appealed. If the site is not stabilized, significant damage to resource areas may occur during the interim period.

Before revoking an Order, be sure to give the permit holder his or her due process rights. "Boilerplate" Condition No. 1 found on DEP's Form 5, Order of Conditions, 310 CMR 10.99, gives every recipient of an Order of Conditions notice that the order can be revoked for failure to comply with all conditions, related statutes, and other regulatory measures.

However, your commission should not rely on this provision to provide adequate notice to the violator. Upon discovering a violation that is serious enough to warrant revocation, you must notify the violator of your intended action and provide an opportunity for the violator to present evidence on his/her behalf at a public meeting. This meeting should be advertised and conducted in accordance with the open Meeting Law, and must be held before your commission makes a final decision. After the violator has presented his/her case, the commission should take a formal vote. If revocation is approved, the vote should be documented in writing. 
Be absolutely sure you make a complete record of the reasoning behind your decision. Enter into the record evidence of the violations and your attempts. to gain compliance. The record must show, on its own, that your Commission has not acted capriciously or arbitrarily. If appealed, a judge will review your record under this standard.

A Commission has authority to revoke only those orders it has issued, not DEP Superseding Orders. Be sure that your Enforcement Orders provide for the continuation of work deemed essential to stabilize the site. Once the order is revoked, the Enforcement order comprises the only authorization for work on the site. Also be sure to send all notices and Orders via certified mail, return receipt requested, or by hand delivery.

The Revocation Order can be recorded in the Registry of Deeds as long as your commission's signatures have been acknowledged by a Notary. Have the commission sign two original copies of the Revocation Order. Send one to the violator (certified mail, return receipt requested or hand delivery); record the other at the Registry of Deeds.

Your commission may use the Enforcement Order Form 9, 310 CMR 10.99 ,... to revoke an Order of Conditions as long as the following changes are made:

1) Add to the title of the form the words, "Revocation of Order of Conditions".

2) Add a notary acknowledgement to the end of the form so that the Revocation order can be recorded in the Registry of Deeds. This acknowledgement should read:

On this day of 19 , before me personally appeared person described in and who executed the foregoing instrument and acknowledged that he/she executed the same as his/her free act and deed. 
10/93 Update Note: Massachusetts General Law Chapter 40, Section 21D, the non-criminal "ticketing" procedure used to enforce local bylaws, was substantially amended in 1992. These amendments were to have taken effect on January 1, 1993, and have caused considerable confusion among municipalities, District Courts, and the motor vehicle registrars. As a result, legislative amendments are again proposed (and, as you read this, may have already been signed into law) to correct the situation and restore section 210 to its previous format.

The 1992 amendments rewrote much of section 21D by substituting, in full, the procedures for writing tickets and collecting fines that are found in G.L. Chapter 90G - the "Civil Infractions" law. An important consequence of this amendment is that Chapter $90 \mathrm{G}$ requires all ticket fines be paid to the registrar of motor vehicles rather than to municipalities directly. The registrar would then distribute the monies to the municipality which issued the original ticket. In the event a violator does not pay the fine, the registrar is authorized to withhold drivers licenses, motor vehicle registrations, and similar documents until the fine is paid in full.

For a number of reasons, this enforcement scheme has not been implemented. As of this writing (10/93 update), legislative amendments to restore section 21D have passed both the Massachusetts House of Representatives and Senate and are awaiting the Governor's signature. Additional amendments are planned.

The following sections on 21D, while describing past practices, still contain useful information about this "ticketing" procedure. The legislative amendments described above, in fact, may restore the procedures of the former law and these following sections may again apply.

Before taking any action under Chapter 40 , section 21D, consult your town counsel or city solicitor for the most current statutory language and for advice about how to proceed.

If your community has a local wetland bylaw, there is another enforcement technique which can be used to bring about compliance before escalating to a law suit. The legislature has authorized municipal governments to use a non-criminal "ticketing" procedure to enforce local laws such as wetland bylaws. As long as the appropriate bylaws are in place, the "ticketing" procedure can be used as an alternative or an additional enforcement tool. 
The "ticketing" statute, G.L. C.40, s.21d, provides that any ordinance, bylaw, rule, or regulation of any municipal office, board, or department may be enforced by this method as long as the violation is subject to a specific penalty. Only a few towns have actually adopted this process; some have made it applicable to a few specific bylaws while others have given it more wide-ranging applications.

Typical environmental laws enforced by this method include wetland bylaws and regulations, conservation land rules and regulations, rubbish disposal and littering regulations, shellfish regulations, and violations of zoning bylaws.

Use of the "ticketing" procedure allows an enforcement person. to write a ticket which provides for a specific sum of money to be paid as a penalty for the violation of a local bylaw. The violator must pay the ticket or request an appeal in writing to the district court. If appealed, a hearing will be held on the matter within twenty-one days following the date the ticket was written.

Advantages to use of the non-criminal ticket include: the "criminal" stigma is taken away from enforcement efforts; the need to prove a case in a trial setting is for the most part eliminated; and many local bylaws can be enforced by a process similar to that employed for minor traffic violations, a process with which most people are familiar.

In order to take advantage of the ticketing procedure, your municipality must first adopt a bylaw authorizing its use. The bylaw must specify if the procedure is to be mandatory or optional. The bylaw also must specify who the enforcement persons are to be and the specific penalty which is to apply for violations of each particular provision.

Existing municipal bylaws typically provide for enforcement in a general way and do not include specific fines or name enforcement personnel. If your community wishes to use the ticketing procedure to enforce multiple bylaws, it may be difficult to amend each individual bylaw to include the required information. It may be easier to create a new bylaw which authorizes use of the ticketing procedure and, at the same time, references each individual bylaw, giving specific penalties and naming enforcement personnel. Police officers and conservation commission members and staff should be named as enforcement personnel for purposes of enforcing the local wetland bylaw. A model bylaw is included in Appendix $\mathrm{H}$. 
Before adopting an enabling bylaw, it is strongly recommended that a conference be held with a clerk or magistrate of the local district. court in order to advise them of the action and to secure advice. Proper enforcement under these provisions requires close cooperation between the municipality and court. To omit the meeting, or to delay it, may adversely affect the town's implementation plan and efforts.

b. Issuing the Citation

Citation forms must be developed for use by commission members and other enforcement personnel. A sample form is included in Appendix I. At a minimum, the form must be prepared in triplicate: one copy for the violator, one for the court, and one for the municipality. If the forms are printed in four parts, your commission will be able to retain a copy for its files. A list of provisions subject to enforcement by this procedure and a schedule of fines should be kept in the citation book.

There should be space on the citation form (at least on the back of the copy retained by the enforcement officer) for an incident report. If there is no room for an incident report, enforcement personnel should be directed to keep their own notes concerning the violation. If a hearing is requested by the person being cited, or if a criminal complaint must be issued, these notes will be essential:

A set of detailed instructions should be issued, particularly for the non-police enforcement personnel. A sample set of instructions is included in Appendix J. Hands on training should be provided before enforcement personnel are permitted to issue any citations.

c. Collecting the Fine

Fines in the $\$ 25$ - $\$ 50$ range appear to be the most successful based upon other communities' experiences. Fines in this range are large enough to be noticeable when paid by an individual but are low enough so that they will be paid, rather than contested. One community, which adopted fines in the $\$ 100$ range, has found that the majority of.its tickets issued under these provisions are contested. Ascending scales (fines go up with each subsequent offense) may be considered, but the additional burden to administrate such a system may be prohibitive.

A list of all citations issued, the date of issuance, the date by which a response is due, and action taken should be recorded. Usually this will be the duty of the police prosecutor. The commission may wish to. keep its own log 
sheet covering wetland/conservation violations. The list is necessary for accurate follow-up once the citations have been issued.

If twenty-one days have elapsed since a ticket was issued, and the person cited has not paid the fine or requested a hearing, a follow-up letter can be sent. The letter is optional, and can grant an additional ten days for the violator to act before facing a criminal complaint.

If the violator responds by paying the fine, the matter is closed and no record of the case is entered with the court. If the violator requests a hearing, he/she must appear before a judge, magistrate, or clerk. If the court finds that the offense was not committed, or that the person appearing did not. commit. it, the matter will be dismissed. If the court finds that the offense was committed by the person cited, the person may then pay the fine and the matter will be disposed of without a criminal record.

If the violator does not respond to the citation, the enforcement officer should speak with police to discuss the case and its suitability for requesting a criminal complaint. Issuance of a criminal complaint is discussed in Section IV-C below. 
A. Suing the Violators

If a violator repeatedly or flagrantly has violated the Wetlands Protection Act or local bylaw, or is causing serious, potentially irreparable harm to the environment, legal action may be necessary. A lawsuit also may be the only way to command attention from a violator who has not or will not respond to commission phone calls and Enforcement orders. If you decide to proceed with legal action, your case will be much stronger if you have followed the suggestions made in preceding sections for collecting facts, organizing the record, and building support from other municipal boards.

In fact, if you have not followed these suggestions, by collecting facts and establishing a record, it may be impossible to bring a legal action. In addition, if your conservation commission or your fellow municipal boards have in any way permitted or condoned the illegal activity - by explicit or implicit approval of the illegal activity or by extreme delay in taking enforcement action after receiving evidence of the violation - then a judge's view of the enforcement case may be adversely affected. The longer wetlands violations are allowed to continue, the less likely it will be that effective legal action will be an option.

1. Statute of Limitations

Statutes of limitations define the time within which any person can bring a lawsuit against another party. The statute of limitations applicable to the Wetlands Protection Act is found at MGL Chapter 131, $\$ 91$. Prior to the Grant amendment, effective December 26,1990 , the statute of limitations was a significant problem for wetlands enforcement. With the passage of the Grant amendment (Chapter 388, Acts 1990), leaving fill in a wetland or failure to restore an altered wetland is a continuing violation. Now, all violations are essentially treated the same for purposes of the statute of limitations. Any action must be brought within two years of the date the violation occurred. If the violation consisted of removing, filling, dredging or altering, then the action must be brought within two years of the date the violator removed, filled, dredged or altered a wetland.

If the violation consists of maintaining unauthorized fill in a wetland or failing to restore an illegally altered wetland, then each day the fill stays in a wetland or the wetland fails to be restored, is viewed as a separate violation. Therefore an action for such violation must be 
brought within two years of the last day such violations occurred.

All violations, be they removing, filling, dredging or altering; or maintaining fill, or failing to restore, can be prosecuted criminally for fines or imprisonment, or civilly for fines or removal and/or restoration. One exception to this rule arises in situations where a piece of property has changed hands. Then, any otherwise timely suit must be brought within three years after the date of the property transaction.

2. Selecting Criminal vs. Civil Enforcement

Legal action can be brought for a number of reasons: site restoration, completion of unfinished work, punishment, or deterrence. Civil or criminal litigation can be used to obtain corresponding remedies, from court orders requiring specific restoration work to the imposition of fines and jail sentences. The choice between civil or criminal litigation is determined by what the commission hopes to accomplish with the lawsuit. These distinctions are more fully described in the following section.

Civil lawsuits generally are useful to compel compliance with a procedural requirement or permit condition under the Act or local. bylaw. A civil lawsuit can obtain an injunction or similar court order to forbid action (a prohibitory injunction, for instance, halting wetland alterations) or to require action (a mandatory injunction, for instance, requiring filing a Notice of Intent). In other words, injunctive relief should be sought when the commission wants violations corrected and natural resources protected. In addition, a civil action seeking money damages is appropriate where there has been injury to persons or property. Once a civil lawsuit has been filed, the commission may seek a Temporary Restraining Order from the court to immediately stop work on site.

A criminal action, on the other hand, is appropriate when there has been harm to the public health or safety, when a chronic violator has not responded to civil actions, or when the harm cannot be undone and hence there is no effective remedy through injunctive relief. In other words, criminal complaints should be sought in cases of flagrant, malicious, or repetitive violations of the Act or local bylaw which result in significant damage or threat to the environment. The primary goals of criminal prosecution are punishment and deterrence. If convicted, the defendant will acquire a criminal record and be subject to fines, incarceration, or probation terms. The publicity which often accompanies. 
criminal prosecution of environmental crimes has a significant deterrent effect on others who may consider violating the law or ignoring commission orders.

Although a criminal action can achieve both remedial and punitive results with respect to individual violations, civil issues (particularly involving the details of what work can or cannot be done on site) may remain unresolved after the conclusion of a criminal case. Therefore, it may be appropriate to initiate both civil and criminal actions against the same individual for the same illegal activity. When the result of an illegal act constitutes a serious continuing threat to the environment resulting in irreparable harm, it may be advisable to ask town counsel to file a civil complaint and seek a Temporary. Restraining order or a preliminary injunction to mitigate the harm while the criminal action is pending.

Civil complaints are filed in Superior Court, on behalf of your municipality and conservation commission, by town counsel or special town counsel. Typically, approval. from the board of selectmen is necessary before the commission can utilize counsel's services. Your commission retains control of the lawsuit, in the sense that it can work with and assist town counsel, but the town incurs all the costs. Civil lawsuits are won and lost at trial by convincing the judge or jury by a "preponderance of the evidence" that a defendant violated the Act or local bylaw.

In contrast, a criminal action can be initiated by anyone, simply by seeking a complaint in District Court. Criminal complaints can be sought for violations of the Act, local bylaw (if criminal sanctions are authorized in the bylaw) or both. If a criminal complaint issues, the action is prosecuted by the District Attorney's office or the Attorney General's office (or in some cases by attorneys specially appointed as Assistant District Attorneys) on behalf of the Commonwealth of Massachusetts rather than on behalf of the conservation commission. Consultation with town counsel is certainly appropriate, but town counsel's approval is not necessary in order to proceed with a criminal case. At trial, the prosecution must prove each element of the offense "beyond a reasonable doubt." This is a much higher standard of proof than that necessary in civil cases, where the allegation must be proved by a "preponderance of the evidence." 
1. Filing the Complaint

The procedure involves town counsel filing a civil complaint in superior Court, on behalf of the municipality and the local board, against the violator. Your commission must have an attorney file and press a civil action, and this means you must get approval from the board of selectmen to utilize legal services. If the selectmen or counsel are not enthusiastic about enforcing the law, this request for services should be made in writing setting forth the reasons litigation is warranted and the date by which the commission requests that the complaint be filed. A realistic time span would be ten days to two weeks, except where the offending activity will cause irreversible harm. In that case the complaint should be filed immediately, so a Temporary Restraining Order can be sought the next day.

2. Temporary Restraining Order (TRO)

If your commission wants to stop illegal work immediately, a Temporary Restraining Order (TRO) should be sought. A TRO can be requested as soon as a complaint is filed in court. It is a form of initial relief which the court may issue, in its discretion, even without hearing from the defendant. Consequently, it is effective for only a short period of time, usually no more than ten days, until the preliminary injunction hearing can be held. Typically; a TRO will maintain the status quo on site until the preliminary injunction hearing.

To secure a TRO the commission must be able to demonstrate to the court that, without the restraining order, there will be irreparable harm; the restraining order will not cause irreparable harm to the defendant; the commission has a reasonable chance of winning the case on the merits at trial; and the public interest warrants issuing the order to halt some work or activity.

3. Injunction

Injunctions are the mainstay of environmental law. An environmental suit may be won or lost on preliminary or permanent injunction issues. A preliminary or permanent injunction not only may prohibit illegal acts but also may compel affirmative action. For example, an injunction could require that a Notice of Intent be filed and forbid any further activity on site until an order of conditions has been issued. Once an injunction is issued, its strength lies in the broad authority of a court to demand relief if the defendant violates the injunction. Since the injunction 
is a court order, the defendant would be in contempt of court for any violation and subject to criminal sanctions.

A hearing for this type of court order may be consolidated with a trial on the merits of the case. In some situations, a trial on the merits will not be heard until months after the preliminary injunction hearing. Without a preliminary injunction, illegal work may be completed in the interim and the case made moot or relief made more difficult.

To secure an injunction the commission must be able to demonstrate to the court that, without the injunction, there will be irreparable harm; the injunction will not cause irreparable harm to the defendant; the commission has. a reasonable chance of winning the case on the merits at trial; and the public interest warrants issuing the order to halt (or compel) some work or activity.

A sample complaint requesting a TRO, preliminary injunction, and permanent injunction is included in Appendix K. Town Counsel should be prepared with affidavits (sample included in Appendix L); applicable provisions of the Wetlands Protection Act, Regulations, and local bylaw; a legal brief demonstrating a good chance of success on the merits; and testimony on key points. The issues of irreparable harm and chance of success on the merits are most likely to determine whether an injunction is issued. 
1. Application for a Criminal Complaint

A criminal action may be initiated by any person. This means that any member of the public, including individual commission members or staff, may visit the district court with jurisdiction over the location where the violation occurred and fill out a request for a complaint to issue.

The application for the complaint is merely a brief statement of the violation specifying the type and extent of the violation; name and address of the violator; location of the violation; date of the violation; and the statute

(Wetlands Protection Act and/or local bylaw) which has been violated. A sample application for a criminal complaint is included in Appendix $M$. The person applying should indicate that this application has been approved by vote of the commission and should provide names and addresses of witnesses to the violation plus properly prepared photographs. If there is a permit, Violation Notice, Enforcement order, or other relevant document, include it.

Since a violation of the Wetlands Protection Act or bylaw is a misdemeanor, a potential defendant usually will be entitled to a."show cause hearing" on the issue of whether or not a complaint should issue. At this hearing a clerk will hear evidence under oath from the person seeking the complaint and perhaps from the violator. If the clerk finds "probable cause" to believe that the person has committed the crime alleged, a complaint will issue. Probable cause means that there is a reasonable basis for believing that a crime was committed and that the alleged defendant did it.

2. Prosecuting the Complaint

After probable cause is determined and the complaint is issued, the District Attorney's or Attorney General's Office retains sole discretion in deciding whether and how to prosecute the criminal case. The District Attorney may seek assistance from your commission, but your commission has no authority to determine how or when the case will proceed.

After a complaint issues, the defendant will be given a date for arraignment in District Court. At the arraignment the defendant is given formal notice of the charges pending against him/her; the defendant enters a plea to the charges (guilty, not guilty, nolo contendere); pre-trial conditions may be set; and a schedule for pre-trial options and the trial itself are set. At trial the prosecution must prove each element of the offense "beyond a reasonable doubt." This is a much higher standard of proof than that necessary 
in civil cases, where the allegation must be proved by a "preponderance of the evidence." A criminal defendant is entitled to constitutional protections which may not be applicable to civil cases. For example, in a criminal case the defendant has the right to remain silent, the right to counsel, and the right to confront witnesses.

\section{Criminal Penalties}

If found guilty, the penalty typically imposed is a criminal fine, as specified in the applicable statute. A jail sentence is rare. A period of probation with "no same or similar violations" is a good thing to seek. Currently the penalty provisions of the Wetlands Protection Act impose very stiff fines compared to other environmental violations. The Act provides: "Whoever violates any provision of this section, (a) shall be punished by a fine of not more than twenty-five thousand dollars or by imprisonment for not more than two years or both such fine and imprisonment; or (b), shall be subject to a civil penalty not to exceed twentyfive thousand dollars for each violation. Each day such violation continues shall constitute a separate offense. This section may be enforced by environmental officers, and any officer having police powers." G.L. C.131, s.40.

Be sure to build bridges of communication with the District Court staff and the office of the District Attorney. A criminal prosecution is not handled by town counsel, except in unusual cases. An Assistant District Attorney will handle the prosecution. If you wait until the last moment and contact the District Attorney's Office just before trial, the result is predictable. If you consult with the District Attorney before seeking the complaint, you will have a much greater chance of success. 
V. INVOLVING OTHER AGENCIES IN ENFORCEMENT ACTIVITIES

A. Involving DEP

DEP and the conservation commission equally are authorized and responsible for enforcing the Wetlands Protection Act. This means that:

1. A conservation commission, at its discretion, can enforce a DEP Order. The DEP regional office should be notified as quickly as possible of any violations of Superseding Orders. If DEP supports enforcement actions by the conservation commission, but is unable to respond quickly enough or at all, the commission should proceed promptly with its own enforcement action.

2. DEP, at its discretion, can enforce a conservation commission Order. The state may take enforcement action if the person requesting such action has reasonably documented improper or no action by the commission, or if requested by the commission for good cause. DEP encourages commissions to enforce their own Orders.

3.. Both DEP and the conservation commission can pursue a violation where work is being done in an area subject to the Act without a valid Order.

If town counsel fails to respond to the written request of a conservation commission for legal enforcement action, or if your commission is unsuccessful in enforcing a state Superseding Determination or Order, your commission can seek help from the state. A letter requesting support in an enforcement action should be sent to the DEP Regional Environmental Engineer with a copy to the Environmental Protection Division of the Department of the Attorney General (See Contact/Reference List). Complete documentation including copies of the Enforcement order and correspondence with town counsel should be enclosed. When requesting this assistance it is important that your commission demonstrate that it has made every effort to deal with the problem at the local level.

There are a number of factors that the state will take into consideration in deciding whether or not to pursue enforcement action, including the seriousness of the violation, the degree of environmental harm, the likelihood of preventing future violations, the availability of enforcement resources and the probability of achieving a successful result. If DEP determines litigation is necessary, the case will be referred to the Attorney General's Office or the Environmental strike Force. Such 
referral means that, should no settlement be reached, conservation commission members and other town officials must be prepared to do the work required to go to court.

DEP also may enforce wetland violations through the Administrative Penalties program discussed in section VII-D.

B. Involving the Environmental Strike Force

The Massachusetts Environmental Strike Force (ESF) is an inter-agency unit (DEP, Attorney General's Office and Executive Office of Environmental Affairs) designed to identify and prosecute major environmental violators through civil and criminal actions brought by the Attorney General's Office. If you feel you have a recalcitrant wetlands violator who has not responded to local actions, you should consider referring the case to the Strike Force through the DEP Regional Strike Force staff person identified in the Contact/Reference List. Please be prepared to provide a full description of the alleged violation(s). The ESF can provide investigative, technical, and legal resources in appropriate cases.

C. Involving Local Boards

1. Board of Health

The municipal health board controls a vital aspect of land use planning - disposal of sanitary wastes in non-sewered areas. Your commission and board of health should make every effort to understand each other's concerns and jurisdiction. Make sure each board of health member, and in particular, the health agent, can identify wetland resource areas so they can alert you to potential problems. Discuss with the board how septic systems may be sited so as not to damage streams, lakes, wetlands, and coastal resources, and urge the board to adopt stiffer local regulations if topography, soil conditions, or presence of a local drinking water source merit them.

In sewered areas, check with the sewer commissioners to assure that the system is properly maintained and not discharging contaminants into wetlands or surface waters.

2. Planning Board

Responsibility for much municipal planning lies with the planning board. Not only can the board undertake comprehensive studies and prepare master plans, but also it can regulate the development of subdivisions. Again, a 
close relationship between the commission and the planning board is advisable. Projects with potentially serious wetland impacts may be filed with the planning board months before they are filed with the conservation commission. If the planning board can identify wetland resources in the field, they can alert you to potential problems with a proposed or under-construction subdivision.

Work with the planning board to develop and implement techniques that will protect wetland resource areas, such as wetlands/floodplain zoning, cluster zoning, acquisition of conservation restrictions, subdivision rules and regulations and special permit regulations.

3. Building Inspector

This official is responsible to the selectmen or mayor, and has the primary job of ensuring that all local projects are built in conformity with municipal zoning, including wetlands or floodplain zoning. The building inspector can provide the commission with valuable information concerning proposed and on-going developments, because he/she spends so much time in the field. Make sure the inspector understands what a wetland resource area looks like! Good relations with the building inspector can ensure that building permits are not handed out for construction in wetland resource areas without notice to the commission.

4. Zoning Board of Appeals

This board acts more like a court than an administrative body. It guards the zoning bylaw or ordinance by hearing appeals from orders of the building inspector and grants special permits and variances when necessary. Your commission should be aware of and participate in any proceedings for permits or variances in wetland resource areas. Again, it is a good idea to educate each board member about basic wetland resource area identification and functions. 
A. Personal Liability

Municipal employees and officers (including conservation commission members and staff), acting within the scope of their employment or office, are given statutory protection by the Mass. Tort Claims Act, G.I. c.258, from certain types of liability. In some cases the municipality, not the individual, will be held liable for negligent or wrongful acts or omissions caused by a conservation.commission member or staff person acting within the scope of his/her office or employment. For example, individual commission members who acted in good faith in administering the Wetlands Protection Act will not be held liable for flood damage unexpectedly caused by a development permitted under an Order of Conditions.

However, there are numerous exceptions where an individual commission member or staff person could be held liable for actions taken while carrying out his/her duties. Personal liability may arise from acts or omissions which constitute a violation of any person's civil rights under federal or state law. For example, conservation commissioners and staff should not violate constitutional search and seizure provisions by entering onto private property. to conduct a search in the face of landowner objection. Such a search without a warrant could subject individual commission members or staff to a civil rights lawsuit.

Conservation commission members and staff also can be held personally liable for intentional wrongs against another person. These include: assault, battery, false imprisonment, false arrest, intentional infliction of mental distress, malicious prosecution, malicious abuse of process, libel, slander, misrepresentation, deceit, invasion of privacy, interference with advantageous relations, and interference with contractual relations.

B. Mandamus

In Massachusetts, any citizen can bring an action to compel a government agency or official to perform ministerial duties. This type of court order is known as "mandamus." It means that any citizen can sue DEP, or the conservation commission, for failing to carry out a duty required by law. Mandamus is used to enforce statutory deadlines, recordkeeping mandates, notice requirements, and other procedural requirements. 
Mandamus can not be used to compel action that is merely discretionary with the agency or official. For example, mandamus can be used to force a conservation commission to issue an Order of Conditions within twenty-one days, or to take some enforcement action if there is a clear violation of the Wetlands Protection Act, but it cannot be used to force a commission to include a specific condition in the Order, or to issue an Enforcement order worded in a certain way.

C. "Takings".

This doctrine stems from a constitutional prohibition which prevents the government from taking the property of any person without just compensation. It is a requirement of the due process clauses of the federal and state constitutions. It is also the basis for lawsuits which seek to limit the exercise of government authority by claiming that a bylaw, regulation, or permit is so restrictive that it "takes" the landowner's property.

To survive a "taking" challenge, a government restriction, whether in the form of a legislative enactment, permit condition (such as an Order of Conditions), permit disapproval, or Enforcement order must meet three legal tests. These legal standards are sometimes called the "purpose test," the "means test," and the "impact test." Some municipalities make their own mistake in defending a "taking" lawsuit only by documenting police power

justification for the restriction, forgetting to meet the means test and the impact test as well.

First, the restriction must be based on a valid police power purpose. That is, it must have substantial relationship to the public health, safety, or welfare. The courts define these terms broadly and ordinarily will not second guess the decision of a legislature or administrative agency as to whether some public problem needs to be addressed. The Wetlands Protection Act and Regulations clearly define the public's interest in wetlands protection. As long as your commission links its decisions and conditions to the standards in the Act and Regulations, and does not exceed its authority, the "purpose test" will be met. Similarly, Massachusetts courts have upheld local wetland bylaws as furthering valid public interests. Again, as long as your commission links its decisions and conditions to the standards of your bylaw, the "purpose test" will be met. 
Secondly, a police power restriction must utilize a means of implementation which is reasonably related to accomplishing the valid police power purpose. In other words, a legislative or administrative body, acting to protect public health, safety, or welfare, must utilize an approach which is rational to the end. Your commission cannot be

"arbitrary and capricious." Decisions must be well-grounded in fact and in law.

Thirdly, a police power restriction must not have an undue impact on the landowner or other person who is regulated. This does not mean that a landowner has a legal right to make a profit on the development of land, that local agencies must approve the "highest and best use". which appraisers identify, that a developer may sue to force a pie-in-the-sky dream project, or that any particular loss of real estate value is dispositive of the case. Instead, the "impact test" means that the restriction must not deprive the landowner of "all practical uses." Some courts describe this as "all reasonable uses" or "all beneficial uses."

Some developers and town officials think that this doctrine of "regulatory takings" deals with diminution of property value. This is incorrect: Some landowners, eager to use these constitutional doctrines, think of a "taking" lawsuit as a way to get quick cash because they think they can prove that the commission's request for data, or a restrictive Order of Conditions, has reduced their profits - forgetting that the applicable standard is whether the restrictions deprived the landowner of all practical uses.

Even if your commission denies a project, or issues an Enforcement order stopping work and ordering restoration, your commission has not deprived the landowner of all reasonable uses. The landowner almost always has other options. For example, a landowner denied one proposal can file a new Notice of Intent on a modified or scaled-down project. A landowner can comply with an Enforcement Order by correcting the violations, then following the appropriate steps to obtaining an Order of Conditions. In neither case has the landowner been deprived of all use of the property. 
VII. OTHER PROGRAMS RELEVANT TO WETLANDS PROTECTION

A. Chapter 91/Waterways Regulation Program

Massachusetts General Law Chapter 91 authorizes the Waterways Program to regulate development in present or former tidelands, Great Ponds (naturally occurring ponds at least 10 acres in size), and certain rivers and streams.

Adopted in 1866, Chapter 91 ensures that public rights to fish, fowl, and navigate are not unreasonably restricted and that unsafe or hazardous structures are repaired or removed. Chapter 91 also protects the waterfront property owner's ability to approach his land from the water. In addition, Chapter 91 helps protect wetland resource areas by requiring compliance with the Wetlands Protection Act.

DEP administers this program, and if wetland resource areas are involved, will not issue a final license until a final Order of Conditions is issued. Each license issued by DEP must state the conditions on which it is granted. These conditions are enforced by DEP.

Conservation commissions should be aware of Chapter 91 licensing requirements, and should report any unauthorized work, charge in use, structural alteration or violation of an Order of Conditions in a tideland, Great Pond, or river to the DEP Regional Office or the Waterways Regulation Program (see Contact/Reference .List).

B. Coastal \& Inland Wetland Restrictions/Wetlands Conservancy Program

Under the Coastal Wetlands Restrictions Act, G.L. c.130, s.105, and the Inland Wetlands Restriction Act, G.L. c.131, s.40A, restrictions have been imposed on development in certain wetland resource areas after local hearings with formal notice to landowners. Do not confuse these laws with the Wetlands Protection Act. Restrictions and maps are recorded in the Registry of Deeds. Restriction orders under these laws generally permit very few activities in restricted areas. Typically they allow docks, boat channels, foot bridges, floats, utilities, cultivation of shellfish and salt hay, beaches and recreation, and a driveway to unrestricted land of the same owner where other reasonable access is not available. Maintenance dredging also may be permitted. Most other uses including filling and dredging are prohibited. 
Wetland restriction order violations are enforced by DEP in conjunction with the Attorney General's Office, and can lead to stiff fines and a possible jail sentence. Any commission that suspects a wetland restriction order has been violated should contact the Wetlands Conservancy Program (see Contact/Reference List).

\section{Massachusetts Environmental Policy Act (MEPA)}

The Massachusetts Environmental Policy Act (MEPA), G.L. c. 30 , ss.61-62H, sets out a review process designed to inform the public about environmental impacts from projects needing state permits or requesting state funds. MEPA is administered by the Secretary of Environmental Affairs, through the "MEPA.Unit" staff.

Any state agency project, or a private proposal needing state permits or state funds, must file an Environmental Notification Form (ENF) if it exceeds a review threshold for the project size or impact specified in the MEPA regulations. The commission should notify MEPA if it encounters a project exceeding these thresholds.

For projects involving wetlands or waterbodies, the following ENF thresholds are important: issuance of a DEP Superseding Order of Conditions permitting any fill or structure within a regulatory floodway delineated under the National Flood Insurance program; alteration of a primary dune; construction in a Velocity zone on a barrier beach; new, expanded, or reconstructed armoring of a coastal bank; construction of a bridge or road providing access to a barrier beach or construction of utility lines servicing structures on a barrier beach; issuance of Superseding Order permitting any dredging, filling, altering, or removal of 1,000 square feet or more of salt marsh, or 5,000 square feet of bordering vegetated wetlands, 500 feet or more of bank, or one-half acre or more of any other area subject to the Wetlands Protection Act; issuance of any variance from the wetlands or waterways regulations; issuance of a Chapter 91 license for any non-water-dependent use or other large project; and issuance of water pollution permits for discharges over certain levels.

Some projects automatically trigger full Environmental Impact Reports. (EIRs). These include: projects entailing direct alteration of 50 or more acres of land, one or more acres of bordering vegetated wetlands or salt marsh, or ten or more ares of any other Resource Area protected by the Wetlands Protection Act; stream channelization or channel relocation of 2,000 feet or more; Chapter 91 licenses for non-water-dependent use of one or more acres of tidelands; 
new marinas of 250 slips or more; construction of new nonresidential projects with gross interior floor space (excluding structure parking) of 500,000 square feet or more; construction of 350 or more new residential units; and a variety of other large projects.

D. Administrative Penalties

The primary purpose of the Administrative Penalties Act, G.L. C.21A, S.16, is to strengthen enforcement of environmental statutes and regulations by rectifying violations which may have eluded enforcement because of limited state resources:

The Act provides DEP with the power to assess penalties against violators of environmental laws or regulations (without first going to court) through an administrative process in which the initiative for going to an adjudicative hearing or challenging the penalty in court must be taken by the alleged violator, rather than DEP.

Administrative penalties can, and have, been assessed against wetland violators. Commissions can refer serious wetland violations to the nearest DEP regional office for possible enforcement under the Administrative Penalties Act. Complete documentation, including the commission's attempts. to bring about compliance, should be provided to DEP.

E. Water Quality Certification

Under Section $\dot{4} 01$ of the federal Clean water Act, anyone proposing any activity requiring a federal permit that will result in a discharge to waters or wetlands is required to obtain a certification that the project will comply with applicable state water quality standards. For purposes of Section 401, "discharges" include the filling of wetlands for which the U.S. Army Corps of Engineers (Corps) issues permits under Section 404 of the Clean water Act, activities licensed by the Federal Energy Regulatory Commission (FERC), and discharges associated with work in water bodies under Sections 9 and 10 of the Rivers and Harbors Act. Water Quality Certification by the Department ensures that a project will not jeopardize the quality or uses of surface waters and wetlands of the Commonwealth.

A section 404 permit is required from the Corps for the discharge of dredged or fill material to waters of the United States. The term "waters of the United States" defines the extent of geographic jurisdiction of the section 404 program. Waters of the United States includes navigable 
waters and their tributaries, adjacent wetlands, and isolated wetlands as delineated by the Corps. A discharge of dredged or fill material involves the physical placement or excavation of soil, sand, gravel, dredged material or other such materials in waters or wetlands.

DEP's Division of Wetlands and Waterways administers Massachusetts' certification program for projects resulting in the loss of wetlands or dredging $\leq 100$ cubic yards. DEP's Division of water Pollution Control reviews non-wetland 401 projects, dredging over 100 cubic yards, and FERC Iicenses. Any commission that suspects a water Quality Certificate is being violated or has not been obtained should contact the DEP Regional Office.

F. Federal Clean Water Act, Section 404

Section 404 of the Clean water Act regulates the discharge of dredged material into the waters of the United states. Its purpose is to minimize adverse effects of discharges and dredged or fill material through the application of guidelines which prohibit discharges which cause "significant degradation" to the aquatic ecosystem or for which there are practicable, less damaging alternatives. Adoption. of measures to minimize adverse effects of discharges which are allowed must be taken. Section 404 is administered by the U.S. Army Corps of Engineers (Corps), but the U.S. Environmental Protection Agency (EPA) is given responsibility for reviewing permits issued by the Corps.

Section 404 defines wetland resource areas differently than the state Wetlands Protection Act, so the commission's jurisdiction may not coincide with the Corps'. However, in many situations, the Corps and conservation commission do have concurrent, but independent jurisdiction. Therefore, a wetland violation under the state Act may also be a violation under section 404. The commission should notify the Corps whenever unauthorized work is discovered in a wetland.

G. Public Nuisance Suits

The state Attorney General has authority to bring nuisance actions against those whose action or inaction has injuriously affected the safety, health, or morals of the public. Examples related to wetlands protection include actions concerning navigable water obstructions, pollution that results in contamination of public wells or fisheries, and development that results in widespread flooding. The Attorney General can prosecute the case in either civil or 
criminal court. The typical remedy is an injunction to abate the nuisance.

If a private individual can show that he/she has suffered special damages, unlike the rest of the public, he/she can bring an action in private nuisance as discussed below. 


\section{PRIVATE REMEDIES}

A. Nuisance Suits

Private nuisance law prohibits the unreasonable use of property so as to substantially interfere with the use and enjoyment of another's property. Examples include actions involving flooding, drainage changes, water pollution, and drinking water contamination. A plaintiff who can show that he/she has suffered damage due to the defendant's action can recover money damages and request an injunction to abate the nuisance.

\section{B. Citizen Suits}

The "Ten Citizen" statute, G.L. C.214, s.7A, allows any ten citizens of the Commonwealth to bring a civil action for the purpose of enforcing any environmental statute, bylaw, ordinance, or regulation. To enforce a wetlands violation, the "ten citizens" might be commission members, neighbors, members of civic organizations, or individuals concerned about wetlands. The potential defendants also are typically the developer and contractor who are doing the work or the conservation commission which ignored the violation. The statute specifically prohibits the recovery of damages, but authorizes the use of Temporary Restraining Orders, injunctions, and other forms of equitable relief. Successful plaintiffs may recover costs and expert witness fees, but not attorney fees. 


\section{SAMPLE CONDITIONS}

1. The provisions of this order shall apply to and be binding upon the applicant, its employees, and all successors and assigns in interest or control.

2. In conjunction with the sale of any lot governed by this Order the applicant shall submit to the conservation commission a signed statement by the buyer that he/she is aware of an outstanding order of Conditions on the development and has received a copy of this Order of Conditions.

3. In advance of any work on this project the applicant shall notify the conservation commission and at the request of the commission shall arrange an on site conference among the contractor and the applicant to ensure that all of the conditions of this order are understood.

4. The appiicant or its successors shall notify the conservation commission in writing of the identity of the on site construction supervisor hired to coordinate construction during the work on the site and to ensure compliance with this Order.

5. Commencing with the issuance of this Order, and continuing through the existence of same, the applicant shall submit to the conservation commission a written progress report every months detailing what work has been done in or near resource. areas, and what work is anticipated to be done over the next period.

6. The applicant shall have on hand at the start of any soil disturbance, removal or stockpiling, a minimum of hay bales and sufficient stakes for staking these bales. Said bales shall be used for only the control of emergency erosion problems, and shall not be used for the normal control of erosion, as described in the Erosion Control Plan submitted with the Notice of Intent.

7. All erosion prevention and sedimentation protection measures found necessary during construction by the conservation commission will be implemented at the direction of the commission.

8. Members of the conservation commission or its agents shall have the right to enter upon and inspect the premises to evaluate compliance with this Order of Conditions. The conservation commission reserves the right to require, following field inspection, additional information or resource protection measures. 

WHAT TO BRING ON SITE VISITS: A SUGGESTED CHECK LIST

A. "Routine" Visit

Consent obtained from landowner prior to visit

Project file (RFD, NOI, or Order, locus plans, site plans; abuttor comments, etc.)

Notebook and waterproof pens

Tape measure $\left(100^{\circ}\right)$

Plant field guide and/or collecting and sampling materials

Handlens

Camera

Copy of Wetlands Protection Act, Regulations, and local bylaw

Shovel for soil samples

B. Additional. Items for Inspection of Suspected violations (Where you may not have access to the property).

Camera with telephoto lens (High speed film (ASA 400 or 1000) will allow photographs in low light conditions

USGS topographical maps, FEMA floodplain maps, USSCS soil maps, DEP wetland restriction maps, or town wetland maps which identify wetland resources in the suspect area

Aerlal photographs or other photographs showing the area "before" the suspect violation

Binoculars. 



\section{H. 1762 Chapter 388 \\ AN ACT RELATIVE TO WETLANDS PROTECTION}

Whereas, The deferred operation of this act would tend to defeat its purpose, which is to immediately provide for wetlands protection, therefore it is hereby declared to be an emergency law, necessary for the immediate preservation of the public convenience.

Be it enacted by the Senate and House of Representatives in General Court assembled, and by the authority of the same, as follows:

SECTION 1. The twenty-fourth paragraph of section 40 of chapter 131 of the General Laws, as appearing in the 1988 Official Edition, is hereby amended by adding the following two sentences: - In addition to the other duties provided for in this section, a conservation commission and its agents, officers, and employees; the commissioner, his agents and employees; environmental officers, and any officer with police powers may issue enforcement orders directing compliance with this section and may undertake any other enforcement actions authorized by law. Any person who violates the provisions of this section may be ordered to restore property to its original condition and take other actions deemed necessary to remedy such violations.

SECTION 2. Said section 40 of Chapter 131, as so appearing, is hereby further amended by inserting after the twenty-fourth paragraph the following paragraph:-

No person shall remove, fill, dredge or alter any area subject to protection under this section without the required authorization, or cause, suffer or allow such activity, or leave in place unauthorized fill, or otherwise fail to restore illegally altered land to its original condicion, or fail to comply with an enforcement order issued pursuant to this section. Each day such violation continues shall.constitute a separate offense except that any person who fails to remove unauchorized fill or otherwise fails to restore illegally altered land to its original condition after giving written notification of said violation to the conservation commission and the department shall not be subject to additional penalties unless said person fails to comply with an enforcement order or order of conditions.

SECTION 3. The last paragraph of said chapter 40 of said chapter 131, as so appearing, is hereby amended by striking out the last two șentences. 



\section{COMMONWEALTH OF MASSACHUSETTS}

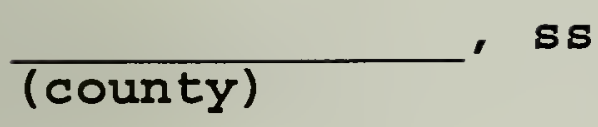

s.
District Court

WARRANT NO.

In The Matter of

\section{APPLICATION FOR ADMINISTRATIVE ENTRY \& INSPECTION WARRANT \\ Pursuant to G. L. C. 131 s. 40}

NOW COMES the

its member/agent,

the information contained in the attached requests that this Court issue an administrative warrant for the entry, inspection, photographing and sampling of the soils and vegetation on the property owned by located at in , Massachusetts.

The requested entry and inspection is authorized by the Wetlands Protection Act, G. L. C. 131 s. 40, subparagraphs eleven and twenty-four. The Act provides, in part, at paragraph eleven:

The conservation commission and its agents, officers and employees and the commissioner of environmental quality engineering and his agents and employees, may enter upon privately owned land for the purpose of performing their duties under this section.

(Pursuant to Chapter $240 \mathrm{~s} \cdot 101$ of the Acts of 1989, the Department's name was changed to the Department of Environmental Protection.) The Act further provides at paragraph twenty-four, as amended by Chapter 388 of the Acts of 1990:

In addition to the other duties provided for in this section, a conservation commission and its agents, officers and employees; the commissioner, his agents and employees; environmental officers, and any officer with police powers may issue enforcement orders directing compliance with this section and may undertake any other enforcement action authorized by law.

Based upon personal knowledge and information received, 
there is probable cause to believe that filling and alteration of resource areas without a permit as required by the Wetlands Protection Act, G. L. c. 131 s. 40 has occurred on these premises. The Conservation Commission therefore offers the affidavit attached and incorporated herein, as specific evidence of an existing violation of a regulatory scheme.

Therefore, the Conservation Commission, in light of the probability of an on-going violation and pursuant to the provisions of G. L. C. $131 \$ 40$, seeks the assistance of this court.

Respectfully Submitted on behalf of the Commission conservation

by :

Signed under the penalties of perjury,

Dated: (signature) (name)

Then personally appeared the above named and made oath that the foregoing application by him subscribed is true.

Signed before me this day of

Notary Public

My commission expires: 
AFFIDAVIT OF. ADMINISTRATIVE WARRANT PURSUANT TO G.L. C. $131 \$ 40$

District Court Department

I， being duly sworn, depose and say:

1) I am a or am a member of the Conservation currently employed by have been a member of the Commission for authorized agent of the Commission for the purpose of investigating and inspecting any records, condition, equipment, practice or property relating to the Commission's duties under the Massachusetts Wetlands Protection Act,.G.L. C.131 $\$ 40$ (hereinafter the "Act").

2) Pursuant to the Act, the Commission has responsibility for implementing standards and requirements for the protection and restoration of wetland areas throughout the Commonwealth. Pursuant to the Act, regulations governing wetlands activities are published at $310 \mathrm{CMR} \$ 10.00$ et seg further defining the Commission's role in enforcing the Act.

3)

located at is the owner of the property Massachusetts. (hereinafter "the premises").

4) Located on the premises is property subject to the jurisdiction of ch. $131, \$ 40$, to wit:

(describe type of wetland or protected area, location relative to structures or geographic features on the premises, and/or append a map depicting the protected area).

5) On (date) , I received information from that the following activities and/or conditions exist on the premises:

Said activities and/or conditions constitutes violation(s) of ch. $131, \$ 40$. 
6) On , at approximately

I attempted to enter and inspect the premises. Said inspection was to be conducted to confirm the existence of violations of the Act on the premises. Prior to the attempted inspection I spoke with

7) I identified myself and requested permission to enter and inspect the premises, stating that based on

, the Commission has reason to believe that there are ongoing wetlands violations on the premises at the present time. Pursuant to the Act, the Commission has authority to enter and inspect the premises.

8) would not permit me to enter the premises and informed me that the only way I would be permitted to enter the premises was with an Administrative Warrant.

9) The Act provides:

The conservation commission and its agents, officers and employees and the commissioner of environmental quality engineering and his agents and employees, may enter upon privately owned land for the purpose of performing their. duties under this section.

Based upon the foregoing circumstances, I seek an Administrative Warrant to:

1. enter the premises located at following activities:

Massachusetts to conduct any or all of the

2. observe any violations of the Act in the area subject to the jurisdiction of ch. 131, $\$ 40$, as described in paragraphs 4 and 5 , above;

3. photograph any evidence of violations of the Act on the premises. 
10) Said inspection shall begin as soon as possible after the issuance of the Administrative Warrant and shall be completed with reasonable promptness, taking into consideration the scope and purpose of the inspection.

11) A prompt return shall be made to the court showing that the inspection has been completed no later than ten (10) days from the date of the issuance of the Administrative Warrant.

THEREFORE, I respectfully request that the court issue an Administrative Warrant authorizing me to enter and inspect the premises to observe, document, sample and photograph evidence of violations of the Act.

Signed under pains and penalties of perjury.

(name)

(date)

Before me, a notary public of the state of Massachusetts, on this day of , personally appeared facts set forth in this application are true to his knowledge and belief.

Notary Public

Mỳ commission expires: 


\section{ADMINISTRATIVE WARRANT AND RETURN}

ISSUED PURSUANT TO G.L.C. $131 \mathrm{~s} .40$

TO THE

ITS PERSONNEL OR DULY AUTHORIZED AGENTS:

CONSERVATION COMMISSION AND

Application having been made this before day of the issuance of an administrative warrant of entry, inspection, sampling and photographing of evidence pursuant to the Massachusetts Wetlands Protection Act, G.L. C. $131 \$ 40$, and the regulations promulgated thereunder at $310 \mathrm{CMR} 10.00 \mathrm{et}$ seg., and the Court being satisfied that there has been sufficient showing that reasonable standards for conducting an administrative inspection have been satisfied.

WE THEREFORE COMMAND YOU, to conduct, during normal business hours, an administrative inspection. of the premises owned by and located at , Massachusetts.

WE THEREFORE COMMAND YOU; to carry out the administrative inspection pursuant to G.L. C. $131 \$ 40$ for the purpose of observing, documenting, sampling and photographing evidence of violations of G. L. C. $131 \$ 40$, which inspection shall consist of one or more of the following activities:

1. entry of the premises located at purpose of inspecting , Massachusetts for the

(describe types of wetland or protected area, location relative to structures or geographic features)

, located on said premises.

2. the photographing of any evidence of violations of G.L. C. $131 \$ 40$ on the premises located at 
YOU ARE FURTHER AUTHORIZED to utilize a Police Officer as you may require to conduct the administrative inspection authorized by this warrant.

WE FURTHER COMMAND YOU to begin said inspection as soon as practicable after the issuance of the Administrative Warrant, with reasonable promptness during normal business hours.

A PROMPT RETURN shall be made to the County District Court Department showing that the inspection has been completed no later than days from the date of issuance of the Administrative Warrant, provided that in the event there is need for additional time you are hereby authorized to request the court for an extension beyond said days.

WITNESS, Justice at day of Esquire, County District Court, aforesaid, this 
I received the attached Administrative Warrant on and have executed it as follows: carried out the authorized inspection. I inspected the following areas took photographs of those areas.

Signature

Subscribed and sworn to me this day of

Clerk Magistrate 


\section{Inspection / Investigation Report \\ Wetland Vlolation Report}

Please complete this report for each violation, or serles of violations, at a location.

1. Date of occurence(s):

2. Locat10n:

3. Owner of Property:

Address :

Telephone No.:

4. Bustaess/Trust Name:

Address:

Telephone No.:

5. Persons Responstble for Violation:

\# N ame:

Address :

Participation:

\$2 Name:

Address:

Partic1pation:

6. Activity: (Check as appropriate)

Remove To Where:

P111 Type:

Dredge Amount:

Alter How: 
7. Equ1pont used:

Vechicles: $\quad$.

License \#

2 .

License \#

3 .

Lfcense

8. Iype of Wetland (check as approprlate):

(a)

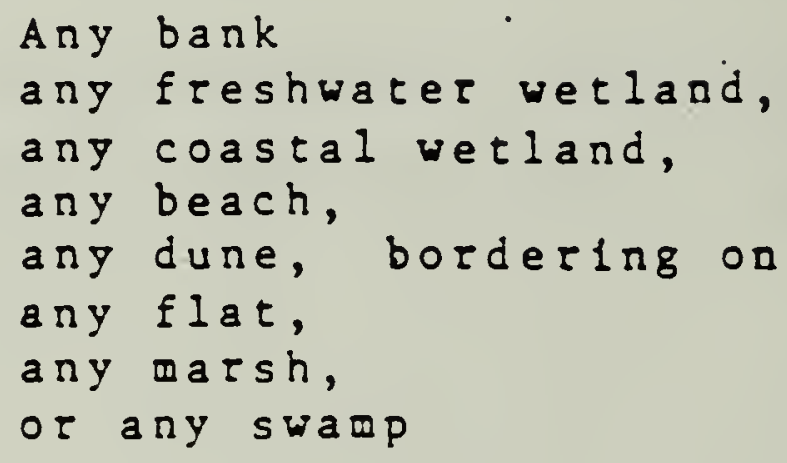

the ocean

any estuary

any creek

any river

any stream

any pond

or any lake

(b) Land under any of the water bodies l1sted above.

(c) Land subject to tidal action.

(d) Land subject to coastal storm flowage.

(e) Land subject to flooding.

9: Notice of Intent filed: date:

(attach copy)

10. Order of Conditions: date:

11. Superseding Order of Cond1tions date:

12. Cease and Desist order(s): date:

Enforcement order(s)

(attach copy)

13. Police Action (if any):

(attach copy)

14. Witnesses:

Name

Address

Telephone

1 .

2 .

3.

4. 
15. Other actions taken: (describe)

16. Conservation Commission Contact Person:

Telephone Number:

Completed by:

Date:

Return to: 

Violation Notice

DEP \#

Issued by the Conservation Commission

Issued to:

Date:

Property:

The Conservation Commission has determined that the activity described below is in violation of the Massachusetts Wetlands Protection Act, G.L. c.131, 8.40 and the Iown of Wetland Bylaw, s.

Extent and type of activity:

If this violation is not immediately addressed as requested below, an Enforcement Order wlil be 188 ued, which may laclude a stop-work order and which may be followed by legal action that could result in fines and/or imprisonment.

Requested ACt10n:

Questions concerning this violation should be directed to the Conservation Commission, telephone

S1gned : 

310 CMR 10.99

\section{Form 9}

DEP File No.

$\because 1$

Applicant

\section{Enforcement Order \\ Massachusetts Wetlands Protection Act, G.L. c. 131, $\$ 40$ \\ and Town of Good Wetlands Protection Bylaw}

From

Good Conservation Commission Issuing Authority

To Not-so-good Developer

Date of Issuance

December 8, 1989

Property lot/parcel number, address

One Main Street

Extent and type of activity:

See attached Enforcement and Réstoration Order

The Good Conservation Commission has determined that the activity described above is in violation of the Wetlands Protection Act, G.L.C. $131, \S 40$, and the Regulations promulgated pursuant thereto 310. CMR 10.00 , because:

Said activity has been/is being conducted without a valid Order of Conditions.

$\square$ Said activity has been/is being conducted in violation of an Order of Conditions issued to dated

File number Condition number(s)

$\square$ Other (specify)

The Good Conservation Commission hereby orders the following:

¿ The property owner, his agents, permittees and all others shall immediately cease and desist from further activity affecting the wetland portion of this. property.

Wettand alterations resulting from said activity shall be corrected and the site retumed to its original con. dition. 
- Completed application forms and plans as required by the Act and Regulatıons snall be filed with the on or before (date).

and no further work shall be performed until a public hearing has been held and an Order of Conditions has been issued to regulate said work. Application forms are available at:

\# The property owner shall take every reasonable step to prevent further violations of the act.

X Other (specify)

See attached Enforcement and Restoration Order

Failure to comply with this Order may constitute grounds for legal action. Massachusetts General Laws Chap. ter 131 . Section 40 provides:

Whoever violates any provision of this section shall be punished by a fine of not more than twenty-five thousand dollars or by imprisonment for not more than two years or both. Each day or portion theieof of continuing violation shall constitute a separate offense.

Questions regarding this Enforcement Order should be directed to: Conservation Commission Agent Issued by . Good Conservation Commission

Signature(s)

(Signature of delivery person or certified mail number) 
ENFORCEYENT AND RESTORATION ORDER

MASSACHUSETTS WETLANDS PROTECTION ACT, G.L. C. 131, \$40

TOWN OF

WEILANDS BYLA'H

This Enforcement and Restoration Order is 1ssucd by the Conservation Commlssion to compel compliance with the Massachusetss Wetlands Protccilon Act and, 1ndependently, the Town of Werlands Bylaw. We order restoration of resource areas lllegally fllled whthout following the procedurcs of state and local law requiring pre-construction review by the Conservation Commission and compllance with design speciflcatlons and performance standards for such work. Th1s Order conf1rms agreement by Mr. through his legol counsel as deseribed below, to carry out this restoracton. Th1s order is issued both to an owner of the property, contractior who performed the work, , and to the Both are independently responsible for the violations since the Wetlands Protection Act and the hictlands Bylaw regulate any person wito dredges, fllls, removes, or alters any of the procected wetlands and related water resources and adjacent arcas whthout the necessary approvals.

\section{FACTS}

Members and agents of the Conservation Commission in November witnessed that a stream was plped and wetlands were fllied and altered on the nateel ot the end of Strect owned by On November, the Commission 1ssuf:d an Fnforcement Order mandating that Mr. case any further alterations of. the land area, requesting that a representat tre appear at the next meeting of the Commission on November, and mandating that completed application forms and plans be flled by December, .

On Deccmber. the Chalman of the Commission, accominaled by the consultant for the Commission, of conducicd a site Inspection and observed that several activities reguinted by the Act and the Bylaw had occurred, lncluding dredging, fllling, removing, and al ccrinc a bank of a body of water, a marsh and frcshwater wetland bordering a body of woter, and land under water, as well as similar activities wthin 100 fect of the bordering vegetated wetlands, all without notiflcation to and approval by the Commission after public hearing. Speciflcally, they observed obvlous evidence of fllling the wetlands and the stream, damolng the stream, extensive grading, construction of roads, diversion of surface wacer, discharge of pollutants including sediment, and destruction of plants. 
weeting on December, - The Comolssion. voted unanimously to issue this Enforcement and Restoration Order. Mr. had flled a Norlce of Incent cn December, seeking approval of this road construction only for coporary access to the rear land to perform percolarion rests. Ar this December meeting, this Notice of Intent was withdrawn by counsel for Mr.

uubsequently, the legal counsel for the Commission visited the site, discussed the matter wich , counsel for Mr.

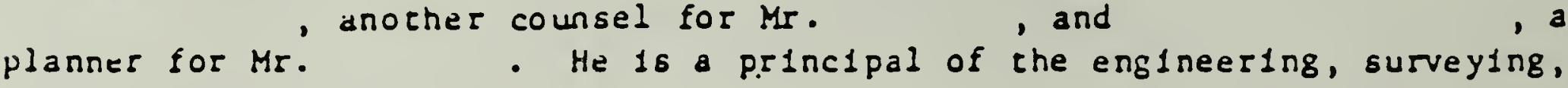
ind planuling firm of accolpanied by Mr. tion by Decenber pluce und setk wetlands and subdlvision approvals, or instead to remove the ruad and rescore the area.

On December, at $5: 45 \mathrm{p} . \mathrm{m}$. , counsel for Mr. telephoned Comisiton counsel to state that Mr. agreed to remove and restore.

\section{CONCLUSIONS}

Both Mr. , as an owner of the property, and Mr. They were

- Counsel for the Comission requested notfficawhether Mr.. Intended to leave the road in performing the work, have violated the Werlands Protection Act and the Wetlands Bylaw. The dirt road, which has been constructed chrough a procecrable resource area composed of a stream, 1ts banks, and the bordering vegetared werlands which extent outward froo 1t, has alcered berween 4,000 and 7,000 square feet of resource area and a significant amount of what is known as the buffer zone. The stream has been plped through a concrete plpe and Jaming of the surface water has resulted. Erosion and consequent siltation are occurring both on the road through the wetlands and on the steep banks near 1t. The approprlate remedy 15 removal of all material from werlands and the restoration of the wetlands and the buffer zone to thelr condition prior co this work. This is essential prior to further fruezing of the solls in order to minlmize the effort necessary within the resource area. This restoration must be accompanied by appropriate erosion control measures. It .2160 is approprlate to take these measures immediately since the onset of snow and the freizing of the ground could lower the affectiveness of erosion control measures. Snow welt and spring flooding would aggravace the problem and cause an increase in curbidity in downsteam water.

\section{ORDER}

The Commsion, In accordance with its voce on December, , hereby orders as follows:

1. The propety owner, his agents, permictees, and all ochers shall lomediacely cease and desise from further activicy affecting the werland portion of thls property and the buffer zone, except as is ordered by this Commission to accomplish restoration and protective weasures required herein. 
2. Niterations of the wetland portion of this property and the buffer zone shall be corrcctcd and the site returned to its origlnal condition to the satisfaction of the Commission.

3. Th1s restoration shall be commenced within 24 hours of recelpt of this order and completed within 14 days of recelpt.

4. Within 24 hours of recelpt of this Order, Mr. or his agent shall telephone the Chalrman of the Conservation Commission at the telephone number shown below to conflum recelpt and agreement to comply.

5. Restoration shall comply with the attached "PROTOCOL FOR RESTORATION OF DISTURBED WETLAND AREAi PARCEL AT dated December., , and the attached "SITE FLAN SHOWING APPROPRIATE LOCATIONS OF RESTORATION ACTIVITIES" prepared by the consultant to the Commission.

6. Within 24 hours of completion of the restoration, Mr. or his agent shall telephone the Chalman of the Conservation Commission to notify the Commission of this completion.

7. Questions regarding thls Order should be directed to Sha1rman, Conservation Commission, the Commission Invites technical questions be directed to the Commission's consultant,

8. It is not necessary for a Notice of Intent to be flled wh the Commssion to carry out this restoration provided lt occurs as ordered here1n.

Please take note that fallure to comply with this order w1l result in further enforcement action by the Coomlasion under both the Wetlands Protection Act and the Wetlands Bylaw. The Bylaw provides for criminal fines of $\$ 300$. The Act provides for a f1ne up to $\$ 25,000$ or imprisorment up to two years. In addition, the Act can be the subject of administrative muney penalties imposed by the Massachusetts Department of Env1ronmental Qual1ty Englneerlng. Each day or portion thereof of continulng violation shall constitute a separate offense.

MAND DELIVERY TO MR.

BY 
CERIIFIED MAIL TO MR.

CERTIFI:D MIIL NO.

DAIE

CERTIFIED MAIL TO MR.

CERTIFIED MAIL NO.

DATE

$c c:$

$D 46 / 46$ 
SAMPLE

PROPOSED AMENDMENT TO GENERAL BY-IAWS

ARTICIE I

Section 1 - Enforcenent

a) Cringral Compla1nt

Whoever violates any provision of those by-lawo may be penalized by 1ndictment of on complaint brought in the district court. Ercept as way be otherwloe provided by law and as the district court may cee f1t to 1mpose, the maximum penalty for each violation, or offense, brought in auch manner, shall be three hundred dollara.

b) Noncriminal Disposit10n

Whoever violates any provision of these by-laws, the violation of which is subject to a specifle penalty, may be penalized by a noncriminal disposition as provided $1 n$ General Laws, Chapter 40, section 2id. The noncriminal method of disposition may also be used for violations of any rule or regulation of any municipal offlces, board or depertient which is subject to a opecific penalty.

Without intending to limit the generality of the roregolng, 1t 18 the intention of this provision that the rollowlng by-laws and sections of by-laws are to be 1 ncluded within the scope of this subsection, that the specific penalties as lisţed here shall apply in ouch cases and that in addition to police officers, who shall in all cases be considered enforelng persons for the purpose of this provision, the municipal personnel listed for each section, If any, shall also be enforclng persons for such sections: each day on which any violation exists Bhall be deemed to be a separate orferge.

GENERAI BY-IAWS

Ast1cle X

Section 10 Dredging. Filling or Altering Wetlands

(Conservation Commission Members and Agent)

Section 13 Lostering

$\$ 50.00$

Section 20. Cusfew

$\$ 50.00$

Section 21 Dumping refuse on private property, without permis810n (Health Agent) 


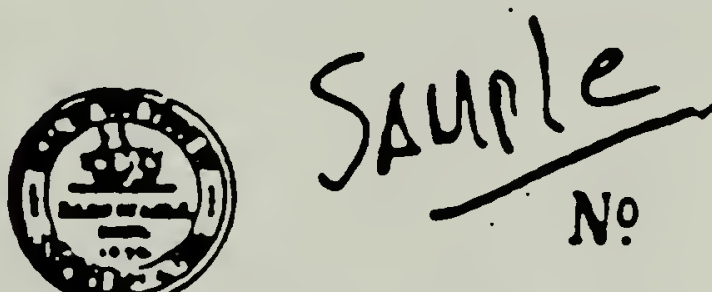

4855

TOWN OF BaRnStaEle nOTICE OF VIOLATION OF TOWM BYLAW OR REGULATION (Oope of mis moices)

To:

(neme of OHancen')

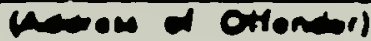

(Cin. Wose. Zip Code)

YOU MAVE BEEN OBSERVED VIOLATING

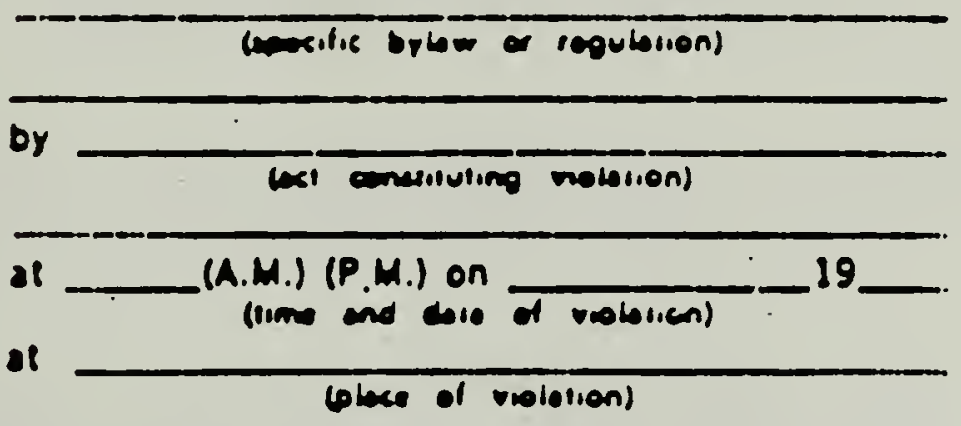

(Sognorure of Entorsing Porion)

I HEREBY ACKNOWLEDGE RECEIPT OF THE FORECOING CITATION:

(sionsivie of allenoer)

Unsble to obtain signalure of oftender.

THE FINE FOR THIS OFFENSE IS \&

YOU HAVE THE FOLLOWING ALTERNATIVES WITH REGARD TO DISPOSITION OF THIS MATTER:

(d) You my elect to pay the obove fine. either by oppesing in person between 9:00 A.M. ino 5:00 P.M. Wonday inrougn Friday. kegl nolidays excepled. belore: THE CLERK.MAGISTRATE

Distriet Cout Deportment

First Barnsuble Division

Count Compound Main Street

Barnsuble, Me. 02630

or by insiling a check, money oroep or postsl note to the Clept Hegistrale WITHIN NWENMTONE (21) DAYS Of THE DATE Of THIS NOTICE. This will opente as - final disposition of the mitter. with no pesulting eiminal record.

(2) If you ossire to contest this matter in a non. criminal procesding. you may do so by making. written raquest to the obove CLERK-MAGISTRRTE for - hearing. A determination by a Judge. Clerk. Megistrate of Assistant Cterk will operate is a $f$. mal disposttion. with no resulting eriminal record. provided any line imposed oy inst officer is puid wilnin ine lime spocified.

(3) If rou tail 10 any the above fine or to ap. par as spaclfied. criminal complaint mey be issued ageinst you.

1 MEREBY ELECT the first option above, con. less to the offence enarged. and enclose piyment in the omount of $s$ 



\author{
Procedures Gulde \\ Non-Criminal Method of Disposition \\ For Violations of By-laws, Rules/Regulations
}

1. Expla1n to offender that you believe a violation of a town by-law, rule or regulation has occursed.

2. Explain to offender that in the exercise of discretionary power bIven to you as an enforcement offlcer for this opecific provision that you intend to $188 \mathrm{c}$ e noncriminal 'ticket' rather than to oek a criminal complaint egainst them.

3. Expla1n the procedurea which are avaliable to orfenders under this process. These are printed on the violation notice 1 taels.

4. Pick up lower end of one complete set of violation notice formg and plece both cardboard cover and metal cover beneath the get.

5. Using a ball point pen, and while pressing down hard (remember you are making multiple copies and the last page must be readable as it is to be a permanent record), fill in the blank spaces provided:

the name and address of the offender

the designation of the opecific oection which

was violated (e.8. Article 7, Section 7, General

By-Iaws) Refer to cardboard cover which contains complete listing of all sections covered by theae procedures.

enter the description of the act constituting the offense, as 1t 18 printed on the card board cover. (e.8. consumption of alcohollc beverage on public property)

enter the tlme, date and place of occurrence

$818 \pi$ your name to the not1ce

enter the applicable IIne (oee cardboard cover)

request the offender to 18 n thels name indlcating recelpt of a copy of the notice, explaining, if necessary, that the elgnature 18 not an admision of gu1lt. 
6. Give offender a copy of the citation, again explain to them the procedures to be followed, ell of which are printed on the c1tation form.

7. If offender sefuses to accept the form, or if for any other reason you ase unable to give a copy of the citation to them 1. person, you may me1l or otherwise deIlver a copy to them.

(NOTE: The notlce may be delivered, or malled by the enforcing person, the commanding offlcer, or head of the enforcing person's depertwent, with fifteen days after the $881 d$ violation to the last known addsess of the offender. A certiflcate of the person oo ma111ng a copy ahall be prine racie.evidence of ouch malisig.

8. Two copies of the citation (the original for the district court, and the copy for the town's recosds) wust be dropped of at the Pollce Depertment within twenty-fous houss foliowing isguance of the c1tation. It 18 good practice, uniess otherwise prevented from doing so, to leave al citations at the police departnent at the end of your Working dey.

9. An lroidert report summerizing the ciscunstances in which you have issued each citation must be prepered by you at the time the notice of violation ls witten and kept aveliable until you are edviged it is no longes needed. If the offerder requests a heasing, or if a criminal complaint 18 leter sought, 1 will be necessary to have such a contemporary record of what happened. You will be notified if this becomes necessary. 
NOLFOLK, sS.

TOLIN OF

CONSERVATION CORWISSION,

$\checkmark$.

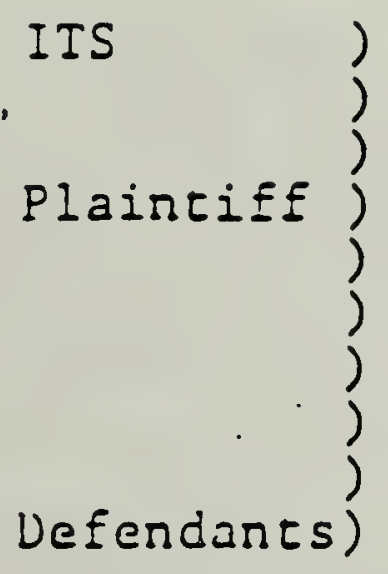

SUPERIOR COURT DEIARTMENT

OF THE TRIAL COURT

C.A. NO.

1. Plaintife, Town of

through its Conservation Comission, duly organized and consticuted in accordance with M. G.I. C. 40, §SC, is charged with the enforcement within the Town of of M. G.I. C. 131, \$40, the Wetlands Protection Act.

2. Defendant,

the premises located at seres. Defendant, also resides at said
to in the exhibits appended hereto and made "premises" refer

3. This Court has jurisdiction over this matter and may order injunctive relief under M.G.L. c. 131, \$40; the Wetlands Prorection Act.

4. Prior to, on or about and subsequent to April 23, defendants have removed, filled, dredged and altered portions of the premiscs that are banks and freshwater wetlands, bordering on crecks or streams and land under said creeks or streams; as well as land subject to flooding. See Affidavit of annexed hereto and made a part hercol as Exhibit " $A$ ". 
5. Said removing, filling, dredging and altering has been performed by defendants without filing written notice of their intention to perform these activities with the plaintiff, as required by M.G. I. c. 131, $\$ 40$.

6. On or about April 23, defendants were delivered a written request by the plaintiff to cease the work, described supra. Said written request also informed defendants of the required procedures under M.G.L. c. 131, \$40, including the required filing of a notice of intent. A copy of the statute was enclosed with this cease and desist request. Said request is appended hereto and made a part hereof as Exhibit " $B$ ".

7. On or ahout April 27, counsel, plaintiff informed defendants' of its request that defendants cease and desist their removing, filling, dredging and altering. Defendants' counsel responded that a superior court judgment determining that installation of a tennis court on defendants' premises did not, under the Zoning Bylaw for the Town of require the permission of any municipal agency, also eliminated the need for defendants to apply to the plaintiff Conservation Commission. A true copy of this judgment is appended hereto and made a part hereof as Exhibit $C$.

8. On or about May 14 ,

plaintiff notified defendants, through. their counsel, that restraint of defendants' removal, filling, dredging and alcering activities would be sought by plaintiff. A true copy of this notification is appended hereto and made a part hereof as Exhibit $D$.

9. At this time the activities of the defendants described supra, are continuing in violation of c. $131, \$ 40$.

10. Plaintiff and its citizens have suffered and are suffering irreparable harm by defendants' activities that are in violation of M.G.I. c. 131, 540 . This harm, if not enjoined, consists of reduced flood scorage capacity and destruction of wetland vegetation; denial of the public right to hearing and comnent upon said activities and their effects; deprivation of plaintiff's right, through its Conservation Commission to review and approve in advance said activities under a bona fide Order of Conditions; and deprivation of plaintiff's right to file such an Order with the Registry of Deeds.

11. No irreparalile harm will occur to defendants if their activities are enjoined, as:

A. these activities are easily postponed;

B. The required Conservation Commission application is simple;

C. The Conservation Commission must hold a public hearing upon such an application within 21 days of receipt of defendants notice of intent; and

D. The Conservation Commission must issue a decision wichin $2 l$ day's of said hearing. 
At most a one and one-half month delay in defendants' activities would occur.

WHEREFORE, plaintiff prays that judgment issue in its favor, and that this Honorable Court issue:

1. A Temporary Restraining Order enjoining the defendants, their agents, attorneys, successors, assigns, contractors and all others acting in their stead or with their consent from any removal, filling, dredging or altering activity upon the premises located at for a period of 10 days or until a preliminary injunction issues;

2. A Preliminary Injunction enjoining the defendants, their agents, attorneys, successors, assigns, contractors and all others acting in their stead or with their consent from any removal, filling, dredging or altering activity upon the premises located at uncil a proper Notice of Intent is filed with the plaintiff and said activities are approved under a proper Order of Conditions in accordance with M.G.L. C. 131, \$40;

3. A permanent injunction following a trial upon the merits enjoining said removal, filling. dredging and aleering by defendants, and ordering defendants to restore the premises at as nearly as possible to its condition prior to the commencement of said activitics;

4. That costs and expenses, including attorneys' fees be ordcred paid to the plaintiff by the defendants; and 
5. Such other relief as this Court may deem appropriace.

By its attorneys,

I, state that the facts alleged in the foregoing complaint are true to the best of my personal knowledge.

NORFOLK, SS.

May 21,

Personally appeared before me the above namec and stated that the facts in this Verified Complaint are to his personal knowledge, on pains and penalties of perjury, true.

Notary rublic

My Commission Expires: 
AFFIDAVIT OF TOWN OF

CHAIRMAN

RE :

CONSERVATION COMMISSION

1. My name is

I reside at

Massachusetts, in Norfolk County. I am the Chairman of the Conservation Commission of the Town of ?

a positior

I have held for more than six years by appointment of the Board of Selectmen. The Commission is charged with administering and enforcing the state Wetlands Protection Act, G.L. Chap. $131, \$ 40$.

2. The defendants

resid-

ing at

are constructing an access

road to a wetland area on a portion of their lot, and filling this area, all subject to the Wetlands Protection Act. They are doing this without filing the necessary information and plans with the Conservation Commission under the statute. Some filling and grading already has taken place, and large piles of fill have been placed on the site, stockpiled for further work, all within the area subject to the jurisdiction of the statute. Photographs have been taken showing this road and other construction activity.

3. On behalf of the Conservation Commission I visited the premises on April 23, .. I spoke to.

and we walked the work area. I explained that the statute requires an application, known as a Notice of Intent, and then the Conservation Commission holds a public hearing, thereafter issuing an approval, known as an Order of Conditions. I indicated the 
Commission was not prejudging what it would decide in this case, but that the Wetlands Protection. Act clearly requires this review and approval for the "filling" and "altering" of this land. indicated he was acting on advice of counsel, and would not stop the work pending the proper applications.

4. On behalf of the Commission I delivered a letter dated April 23, explaining the basic requirements and procedure of the Wetlands Protection Act. I supplied a copy of the statute and told them in the letter where they may obtain the necessary forms for the application. The letter asked that all work on the wetland area cease forthwith. The work is continuing.

5. The legal counsel for the

claims that since no approval is necessary under zoning, no approval is needed from the Conservation Commission. I have explained in a letter to him dated May 14, that the Wetlands Protection Act is completely separate from the Zoning Act and local zoning bylaws. The Conservation Commission administers the Wetlands Protection Act independent of the Board of Appeals under zoning.

6. The filling and altering is occurring in a vegetated wetland and also in a flood-prone area under the statute. This is a bank, flat, marsh, meadow, swamp or freshwater wetland bordering a body of water, namely. a stream, in the language of the statute. Regulations of the state Department of Environmental Quality Engineering (DEQE) under the statute define 
jurisdiction as reaching out to 100 feet beyond the edge of the wetland vegetation. This site is easily within such an area, and the vegetation is predominantly wetland type. In addition, the land is subject to flooding, in the language of the statute. The DEQE regulations define jurisdiction as reaching out to the 100 year flood elevation.

This area is easily within that distance. In fact, the area of work is below the 100 year flood elevation. Moreover, it is very commonly flooded, as is shown on photographs which have been obtained by the Conservation Commission. This filling is not only within the floodplain of the Charles River, it is only a few hundred yards from the river, or even less.

7. At a meeting of the Conservation Commission on May 12. my action in notifying the to cease work was ratified, and it was determined by the Commission to take legal action to enforce compliance with the Wetlands Protection Act. 
8. I make these statements on personal knowledge and under the penalties of perjury.

\section{Town of}

Conservation Commission

\section{COMMONWEAITH OF MASSACHUSETTS}

NORFOLK, SS.

May 21,

Personally appeared before me the above named and stated that the facts in this affidavit are to his personal knowledge, on pains and penalties of perjury.

My Commission Expires: 


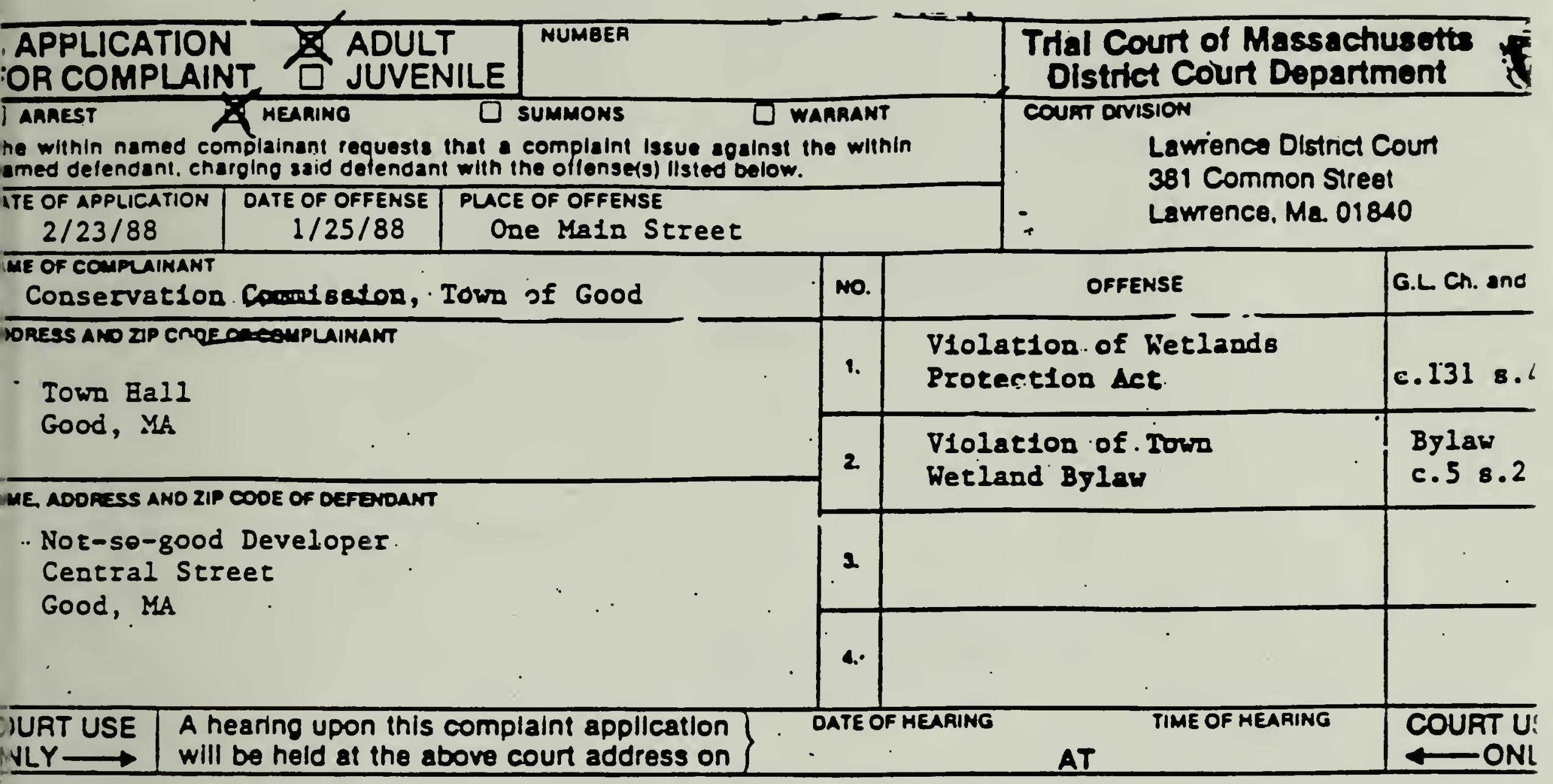

CASE PARTICULARS - BE SPECIFIC

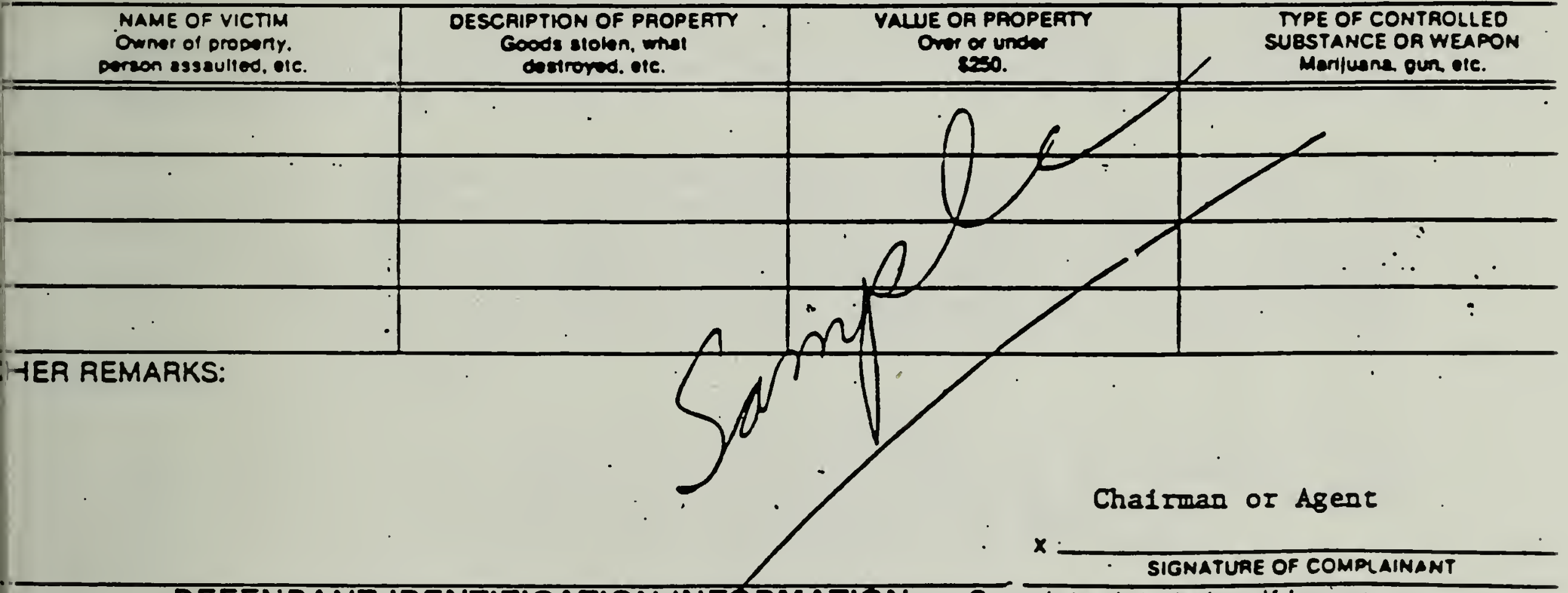

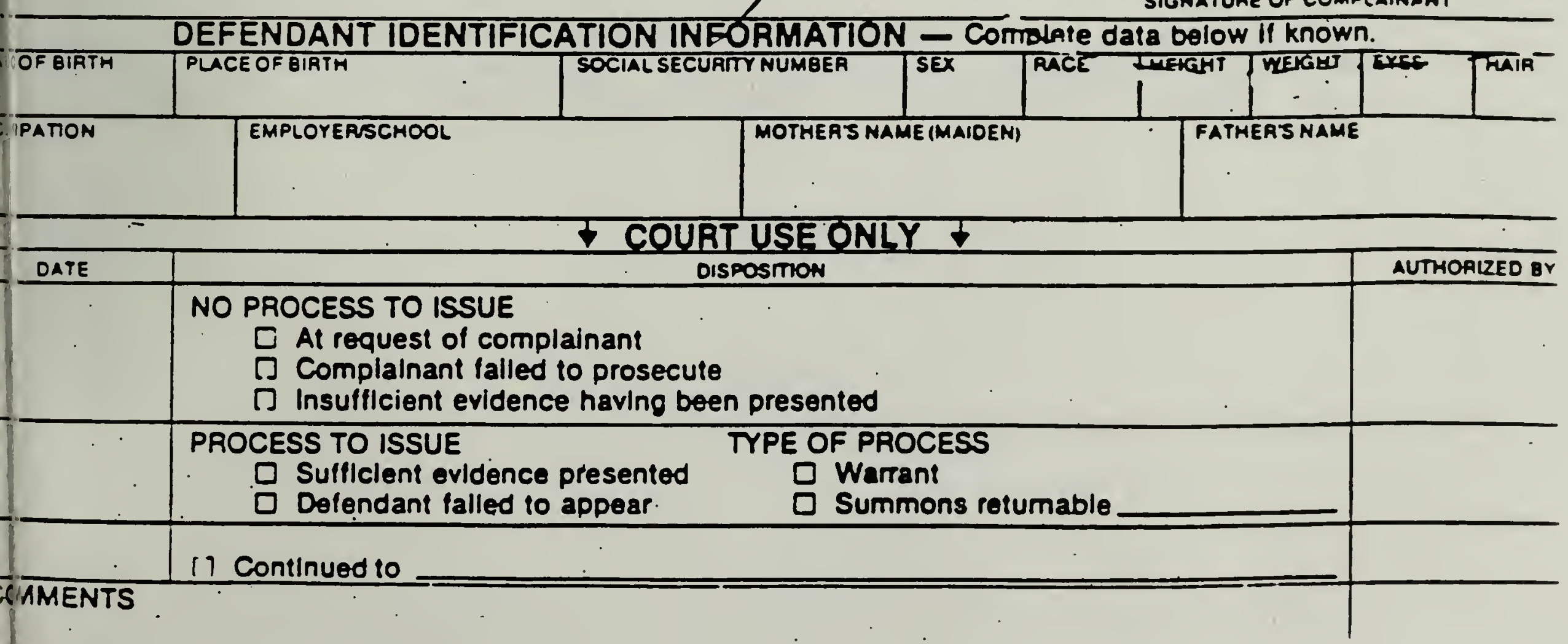





\section{Sample Site Inspection Letter}

[date]

Certified Mail \#:

Return Receipt Requested

RE: Wetlands/[town/city]

Compliance Inspection

Dear [name]:

The [town/city] Conservation Commission has received a complaint that a violation of the Wetlands Protection Act has occurred at your property on [location: street address, town/city]. The activity described consists of: [describe activity: be specific].

In accordance with Massachusetts General Laws, Chapter 131, Section 40, the Commission has scheduled a site inspection of your property. [Name] will be on the site at approximately [time], on [day], [date]. The purpose of this site inspection is to determine if the area is significant to the interests of the Act and to factually determine the existence; nature, and extent of the alleged violation(s).

Please be advised that no unpermitted activity may occur on any portion of the property within 100 feet of any Resource Area defined by the Wetlands Protection Act (MGL Chapter 131, section 40) and/or its implementing regulations, 310 CMR 10.00.

We welcome your presence and participation in this matter. If you have any questions or objections concerning this site investigation, please contact [name] at [telephone number] during normal business hours.

Very truly yours,

[Name]

[Title]

[town/city] Conservation Commission 



\section{CONTACT/REFERENCE LIST}

Massachusetts Agencies

\section{Department of Environmental Protection}

Division of Wetlands and Waterways

Wetlands Protection Program

One Winter Street, 8th floor

Boston, MA 02108

(617) 292-5695

DEP/Northeast Regional Office

10 Commerce Way

Woburn, MA 01801

(617) $935-2160$

DEP/Southeast Regional Office 20 Riverside Drive, Route 105 Lakeville, MA 02347

(508) $946-2800$

DEP/Central Regional Office

75 Grove Street

Worcester, MA 01605

(508) $792-7650$

DEP/Western Regional office

State House West, 436 Dwight street Springfield, MA 01103

(413) 784-1100

Wetlands Conservancy Program One Winter Street, 8th floor Boston, MA 02108

(617) 292-5704

Waterways Regulation Program One Winter Street, 8th floor Boston, MA 02108

$617 / 292-5695$

Division of water pollution Control One Winter Street, 8th floor Boston, MA 02108

(617) 292-5673 
Massachusetts Agencies (continued)

MEPA Unit

Enforcement Division

100 Cambridge Street

Boston, MA 02202

(617) $727-5830$

Dept. of Fisheries, Wildlife, and Environmental Law Enforcement Division of Law Enforcement

100 Cambridge Street, 19th floor

Boston, MA 02202

(617) 727-1614

Metropolitan District Commission

20 Somerset Street

Boston, MA 02108

(617) 727-5215

Environmental Strike Force

One Winter Street

Boston, MA 02108

(617) 556-1000

DEP/Northeast Regional Office

Karen Golden-Smith, Vincent Ferlisi

(617) $935-2160$

DEP/Southeast Regional Office

David Johnston

(508) 946-2708

DEP/Central Regional Office

Craig Dunlop

(508) 792-7692

$\mathrm{DEP} /$ Western Regional Office

Craig Givens

(413) 784-1100

Attorney's General office

Environmental Protection Division

One Ashburton Place, Room 1902

Boston, MA 02108

(617) 727-2200 
Federal Agencies

U.S. Army Corps of Engineers

424 Trapelo Road

Waltham, MA 02254-9149

(617) $647-8220$

U.S. Environmental Protection Agency

Region One

J.F.K. Building

Boston, MA 0.2203-2211

(617) $565-4868$

\section{Non-profits}

Massachusetts Association of Conservation Commissions (MACC) 10 Juniper Road

Belmont, MA 02178

(617) $489-3930$

MACC Western Outreach Office

2 West Street

Hadley, MA 01035

(413) $584-2724$

Massachusetts Audubon Society

208 South Great Road

Lincoln, MA 01773

(617) 259-9500 
Barnstable County

District Attorney

Barnstable Division

3231 Main. Street

Barnstable, MA 02630

508.-362-8113

Berkshire County

District Attorney

44 Bank Row

F.O. Box 1969

Fittsfield, MA 01202

413-443-5951

Bristol County

District Attorney

888 Purchase Street

P.O. Box 94

New Bedford, MA 02740

617-997-0711

Dukes County

District Attorney

3231 Main Street

Barnstable, MA 02630

508-362-8113

Essex County

District Attorney

70 Washington Street

Fourth Eloor

Salem, MA 01970

508-745-6610

Franiklin County

District Attorney

One Court Square

Northampton, MA 01060

113-586-9225

Rampoien County

District Attorney

Hail of Justice

50 State Street

Springfield, MA 01103

413-781-8100 ext. 3009
Hampshire County

District attorney

55 Federal Street Greenfield, MA 01301

413-774-3186

Middlesex County District Attorney Superior Court House 40 Thorndike st. P.O. BoX 38

Cambridge, MA 02141

617-494-4050

Norfolk County

District Attorney

360 Washington Stree

P.O. Box 309

Dedham, MA 02026

617-329-5440

Nantucket County

District Attorney

Superior Court Bouse

Barnstable, MA 02630

508-362-8113

Plymouth County

District Attorney

32 Belmont Street

P. O. Box 1665

Brockton, MA 02403

508-584-8120

Suffolk County

District Attorney

New Court House

Pemberton Square

Boston, MA 02108

617-725-8600

Worcester County

District Attorney

Court House

Worcester, MA 01608

617-775-8601 
ACME

BOOKBINDING CO. INC.

\section{DEC 281999}

100 CARIIÓn at SIREET

CHARLESTOWW. MASS. 
